\title{
Electrocatalysts for Hydrogen Peroxide Reduction Used in Fuel Cells
}

\section{Yusuke Yamada}

\begin{tabular}{|c|l|}
\hline Citation & Anion Exchange Membrane Fuel Cells. pp 141-168. \\
\hline Issue Date & $2018-03-22$ \\
\hline Type & Book chapter \\
\hline Textversion & author \\
\hline Right & $\begin{array}{l}\text { This is accepted manuscript version of the book chapter in Anion Exchange } \\
\text { Membrane Fuel Cells. After it is published, it will be found at: } \\
\text { https://doi.org/10.1007/978-3-319-71371-7_5 }\end{array}$ \\
& This is not the published version. Please cite only the published version. \\
\hline DOI & $10.1007 / 978-3-319-71371-7 \_5$ \\
\hline
\end{tabular}

Self-Archiving by Author(s)

Placed on: Osaka City University Repository

Yamada Y. (2018) Electrocatalysts for Hydrogen Peroxide Reduction Used in Fuel Cells. In: An L., Zhao T. (eds) Anion Exchange Membrane Fuel Cells. Lecture Notes in Energy, vol 63. Springer, Cham. doi:10.1007/978-3-319-71371-7_5 


\section{Electrocatalysts for Hydrogen Peroxide Reduction Used in Fuel Cells}

Yusuke Yamada

Department of Applied Chemistry and Bioengineering, Graduate School of Engineering, Osaka City University, 3-3-138 Sugimoto, Sumiyoshi, Osaka 558-8585, Japan

Tel \& Fax: +81-6-6605-2693

E-mail: ymd@a-chem.eng.osaka-cu.ac.jp

\section{Introduction}

Fuel cells technology has attracted much attention owing to their high conversion efficiency in chemical energy to electrical energy with simple structures, clean emissions, insignificant scale effect, etc. The theoretical conversion efficiency of a typical proton exchange membrane fuel cell operating $\mathrm{H}_{2}$ and $\mathrm{O}_{2}$ as a fuel and oxidant, respectively, reaches $\sim 40 \%$. Other than $\mathrm{H}_{2} / \mathrm{O}_{2}$ fuel cells, various types of organic chemicals including hydrocarbons, alcohols, aldehydes and hydrocarbons, are potential fuels for operating fuel cells. The open circuit voltage of a fuel cell is determined by difference between the reduction potential of an oxidant and oxidation potential of fuels.

Typically fuel cells are assembled by four components that are a cathode, an anode, an ion-exchange membrane, and an external circuit. Under the operation conditions, fuel compounds are oxidatively decomposed into protons, electrons and other products at the anode. The protons thus formed move to the cathode side passing through the ion-exchange membrane, and electrons passing through the external circuit to reduce oxygen to form water. Theoretical output potentials of fuel cells can be calculated from the standard electrode potentials of the reactions at the anode and cathode. The expected output potential of a typical $\mathrm{H}_{2} / \mathrm{O}_{2}$ fuel cell is $1.23 \mathrm{~V}$ based on the following potentials ${ }^{1}$ :
Anode: $2 \mathrm{H}_{2}=4 \mathrm{H}^{+}+4 \mathrm{e}^{-}$
$E^{\mathrm{o}}=0.0 \mathrm{~V}$ vs NHE
Cathode: $\mathrm{O}_{2}+4 \mathrm{H}^{+}+4 \mathrm{e}^{-}=2 \mathrm{H}_{2} \mathrm{O}$
$E^{\mathrm{o}}=1.23 \mathrm{~V}$ vs NHE 
Overall: $2 \mathrm{H}_{2}+\mathrm{O}_{2}=2 \mathrm{H}_{2} \mathrm{O}$

$E=1.23 \mathrm{~V}$

The output potentials of other fuel cells such as methanol/ $\mathrm{O}_{2}$ and ethanol/ $\mathrm{O}_{2}$, were 1.21 and $1.18 \mathrm{~V}$, respectively, which are lower than those of rechargeable batteries currently available in the market, such as lithium ion battery $(\sim 3 \mathrm{~V})$ and lead battery $(\sim 2 \mathrm{~V})$. Higher output potentials with high power density can be achieved by employing stronger oxidant in liquid or solid such as $\mathrm{H}_{2} \mathrm{O}_{2}$ instead of gaseous $\mathrm{O}_{2}$ at the cathode sides, because the standard electrode potential of $\mathrm{H}_{2} \mathrm{O}_{2}$ reduction of $1.77 \mathrm{~V}\left(\mathrm{H}_{2} \mathrm{O}_{2}+2 \mathrm{H}^{+}\right.$ $+2 \mathrm{e}^{-}=2 \mathrm{H}_{2} \mathrm{O} ; E^{\mathrm{o}}=1.77 \mathrm{~V}$ vs $\mathrm{NHE}$ ) is that of $\mathrm{O}_{2}$ (eq. $2 ; E^{\mathrm{o}}=1.23 \mathrm{~V}$ vs $\mathrm{NHE}$ ), and the high density of $1.45 \mathrm{~g} \mathrm{~cm}^{-3}\left(23.4 \mathrm{~cm}^{-3}\right.$ for $\left.1 \mathrm{~mol}\right)$, which allows to assemble fuel cells with high power density. ${ }^{2,3}$ Furthermore, $\mathrm{H}_{2} \mathrm{O}_{2}$ can be easily obtained by two-electron reduction of naturally abundant $\mathrm{O}_{2}$ with various reductants including water. ${ }^{3-8} \mathrm{~A}$ demerit of $\mathrm{H}_{2} \mathrm{O}_{2}$ is an explosive nature that caused by decomposition into water and oxygen by disproportionation, which is catalyzed by various metals and metal oxides. However, $\mathrm{H}_{2} \mathrm{O}_{2}$ can be stored safely even at high concentration by forming adducts with $\mathrm{NaHCO}_{3}$ or urea in the solid state. ${ }^{5}$ Thus, development in superior electrodes for $\mathrm{H}_{2} \mathrm{O}_{2}$ reduction is necessary to construct high power fuel cells. Various electrodes composed of metal, metal oxide and metal complexes have been investigated for electrochemical $\mathrm{H}_{2} \mathrm{O}_{2}$ reduction. In this review, electrocatalysts for $\mathrm{H}_{2} \mathrm{O}_{2}$ reduction used in fuel cells are categorized into three groups that are metal, metal oxide and complexes.

\section{Review of Redox Properties of $\mathrm{H}_{2} \mathrm{O}_{2}$ under Acidic and Basic Conditions}

The standard electrode potentials of $\mathrm{H}_{2} \mathrm{O}_{2}$ oxidation and reduction under acidic and basic conditions are as follows ${ }^{1}$ :

Oxidation (acidic conditions) $: \mathrm{H}_{2} \mathrm{O}_{2} \rightarrow \mathrm{O}_{2}+2 \mathrm{H}^{+}+2 \mathrm{e}^{-} \quad E^{\mathrm{o}}=0.70 \mathrm{~V}$

Reduction (acidic conditions) $: \mathrm{H}_{2} \mathrm{O}_{2}+2 \mathrm{H}^{+}+2 \mathrm{e}^{-} \rightarrow 2 \mathrm{H}_{2} \mathrm{O} \quad E^{\mathrm{o}}=1.76 \mathrm{~V}$ 
In basic solution, $\mathrm{H}_{2} \mathrm{O}_{2}$ forms deprotonated $\mathrm{HO}_{2}^{-}$.

Oxidation (basic conditions) $\mathrm{HO}_{2}^{-}+\mathrm{OH}^{-} \rightarrow \mathrm{O}_{2}+\mathrm{H}_{2} \mathrm{O}+2 \mathrm{e}^{-} \quad E^{\mathrm{o}}=-0.07 \mathrm{~V}$

Reduction (basic conditions): $\mathrm{HO}_{2}^{-}+\mathrm{H}_{2} \mathrm{O}+2 \mathrm{e}^{-} \rightarrow 3 \mathrm{OH}^{-} \quad E^{\mathrm{o}}=0.87 \mathrm{~V}$

The reduction potential under acidic conditions is more positive than that under basic conditions by ca. $0.9 \mathrm{~V}$, suggesting that $\mathrm{H}_{2} \mathrm{O}_{2}$ behaves as more powerful oxidant to provide high power voltage and power density. Additionally, $\mathrm{H}_{2} \mathrm{O}_{2}$ decomposition has been reported to be much slower under acidic conditions than basic conditions as predicted by the oxidation potentials under acidic and basic conditions. Based on these considerations, catholyte of fuel cells should contain $\mathrm{H}_{2} \mathrm{O}_{2}$ together with acids such as phosphoric acid or Lewis acid, metal ions, for both superior electron acceptability and stability to avoid decomposition by disproportionation.

\section{$\mathrm{H}_{2} \mathrm{O}_{2}$ Reduction Catalysts Used in Fuel Cells}

\section{Metal Catalysts}

\section{a. Pt-Based Catalysts}

In general, fuel cells require an electrolyte membrane to avoid thermal reaction of fuel and oxidant on electrodes. However, a fuel cell without membrane can be assembled by utilization of a microchannel reactor, because co-laminar flow is predominant in the microchannel. $\mathrm{A}_{2} \mathrm{O}_{2} / \mathrm{H}_{2} \mathrm{O}_{2}$ fuel cell using a microchannel reactor configuration was constructed employing Pt electrodes for both anode and cathode as shown in Fig. 1A and 1B. ${ }^{9} \mathrm{H}_{2} \mathrm{O}_{2}$ can act as both fuel and oxidant, and reduction and oxidation of $\mathrm{H}_{2} \mathrm{O}_{2}$ are thermodynamically favorable under acidic and basic conditions, respectively. In the fuel cell, acidic $\mathrm{H}_{2} \mathrm{O}_{2}$ solution $\left(\left[\mathrm{H}_{2} \mathrm{O}_{2}\right] /\left[\mathrm{H}_{2} \mathrm{SO}_{4}\right]=2\right)$ and basic $\mathrm{H}_{2} \mathrm{O}_{2}$ solution $\left(\left[\mathrm{H}_{2} \mathrm{O}_{2}\right] /[\mathrm{NaOH}]=1\right)$ were supplied to the Pt cathode and $\mathrm{Pt}$ anode, resulting in electrical power generation with the maximum power density of $23 \mathrm{~mW} \mathrm{~cm}^{-2}$ with the open circuit voltage of $700 \mathrm{mV}$ (Fig. 1C). ${ }^{9}$ 
A
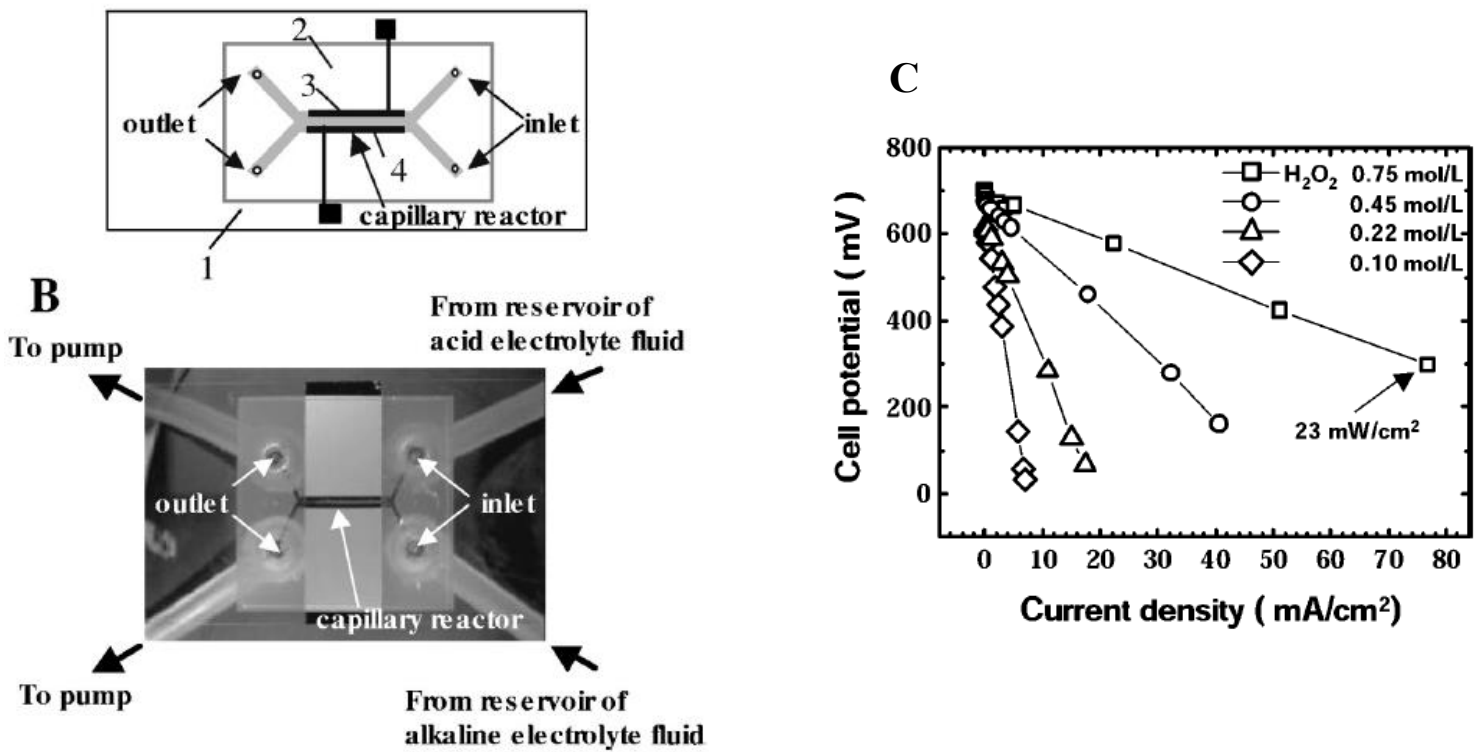

Fig. 1. (A) Schematic drawing and (B) photograph of the microchannel reactor of a $\mathrm{H}_{2} \mathrm{O}_{2} / \mathrm{H}_{2} \mathrm{O}_{2}$ fuel cell. The cell is a simple capillary reactor, where it consists of (1) glass slide and (2) cover glass and epoxy resin spacer (50 $\mu \mathrm{m}$ thick) between them. $\mathrm{Pt}$ electrodes (3) and (4) are placed on the capillary undersurface. Outside the photograph of (B) each inlet and outlet is connected to a fluid reservoir and flow pump, respectively. (C) Cell performance of the $\mathrm{H}_{2} \mathrm{O}_{2} / \mathrm{H}_{2} \mathrm{O}_{2}$ fuel cell at room temperature. At $0.75 \mathrm{M} \mathrm{H}_{2} \mathrm{O}_{2}$ (open squares), the maximum power density is $23 \mathrm{~mW} \mathrm{~cm}{ }^{-2}$ with cell voltage of 300 $\mathrm{mV}$ and current density of $76 \mathrm{~mA} \mathrm{~cm}^{-2} .9$

Such a microreactor configuration without membrane was also applied for constructing a formic acid/ $\mathrm{H}_{2} \mathrm{O}_{2}$ fuel cell and a methanol $/ \mathrm{H}_{2} \mathrm{O}_{2}$ fuel cell. ${ }^{10,11}$ A microreator $\mathrm{HCOOH} / \mathrm{H}_{2} \mathrm{O}_{2}$ fuel cell constructed with $\mathrm{Pd}$ electrodeposited on $\mathrm{Au}$ as the anode and a Pt/Pd cathode exhibited the maximum power density of $30 \mathrm{~mW} \mathrm{~cm}^{-2}$ under the optimized conditions where both anolyte and catholyte contained $2 \mathrm{M}$ phosphate (Fig. 2). ${ }^{10}$ The power density was similar to that achieved for a conventional two compartment $\mathrm{HCOOH} / \mathrm{H}_{2} \mathrm{O}_{2}$ fuel cell using a polymer electrolyte membrane and $\mathrm{Pt}$ based catalysts for both anode and cathode. ${ }^{12} \mathrm{~A} \mathrm{MeOH} / \mathrm{H}_{2} \mathrm{O}_{2}$ fuel cell with a microreactor configuration was constructed with ladder-shaped microchannels to 

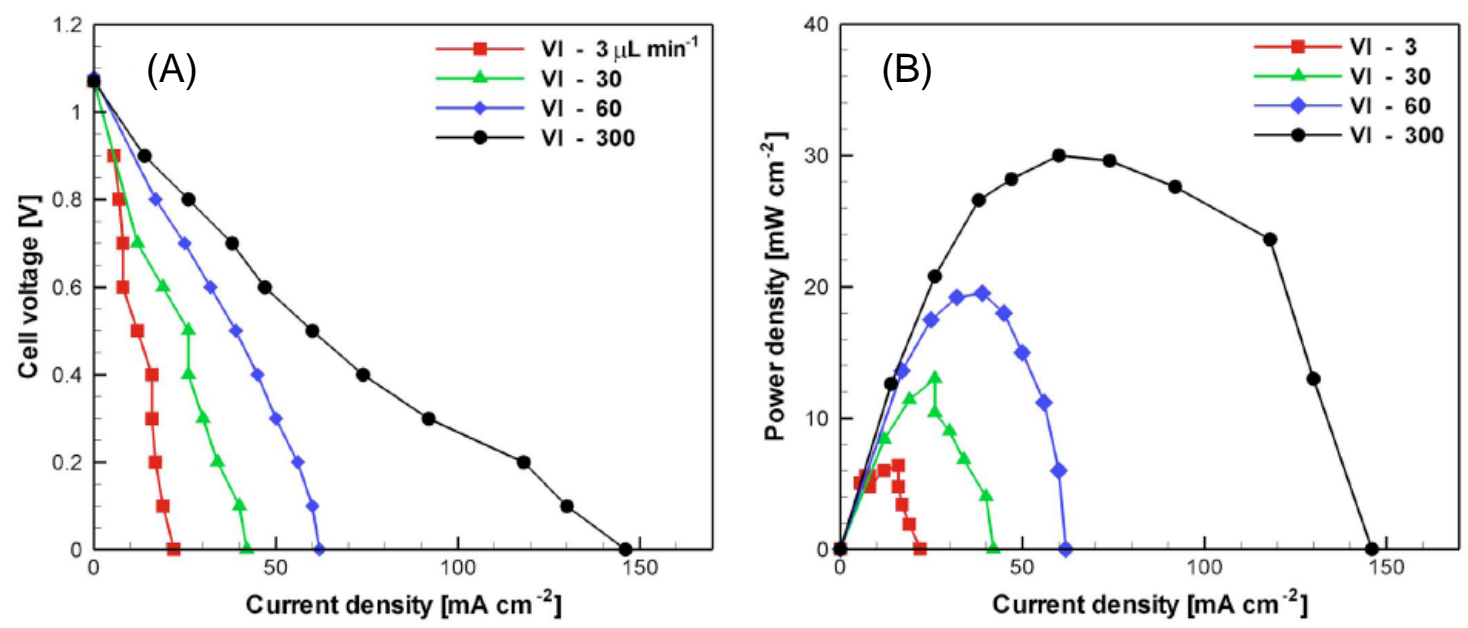

Fig. 2. (A) Polarization and (B) power density curves obtained experimentally at flow rates ranging from 3 to $300 \mathrm{~L} \mathrm{~min}^{-1}$. Fuel cell with $\mathrm{Pt} / \mathrm{Pd}$ cathode $(140 / 70 \mu \mathrm{m}$ channel) was employed using standard solutions $\left(1 \mathrm{M} \mathrm{HCOOH}\right.$ in $2 \mathrm{M}$ phosphate and $2 \mathrm{M} \mathrm{H}_{2} \mathrm{O}_{2}$ in $2 \mathrm{M}$ phosphate). ${ }^{10}$

maintain co-laminar flow firmly (Fig. 3A). The fuel cell was fed with a mixture of $2 \mathrm{M}$ $\mathrm{CH}_{3} \mathrm{OH}$ and $0.5 \mathrm{M} \mathrm{H}_{2} \mathrm{SO}_{4}$ as anolyte and a mixture of $2 \mathrm{M} \mathrm{H}_{2} \mathrm{O}_{2}$ and $0.5 \mathrm{M} \mathrm{H}_{2} \mathrm{SO}_{4}$ as catholyte. The fuel cell with ladder-shaped channel exhibited high maximum power density of $12.24 \mathrm{~mW} \mathrm{~cm}^{-2}$ compared with a fuel cell with normal channel microreactor (Fig. 3B). ${ }^{11}$ The power density achieved for the $\mathrm{HCOOH} / \mathrm{H}_{2} \mathrm{O}_{2}$ and $\mathrm{MeOH} / \mathrm{H}_{2} \mathrm{O}_{2}$ fuel
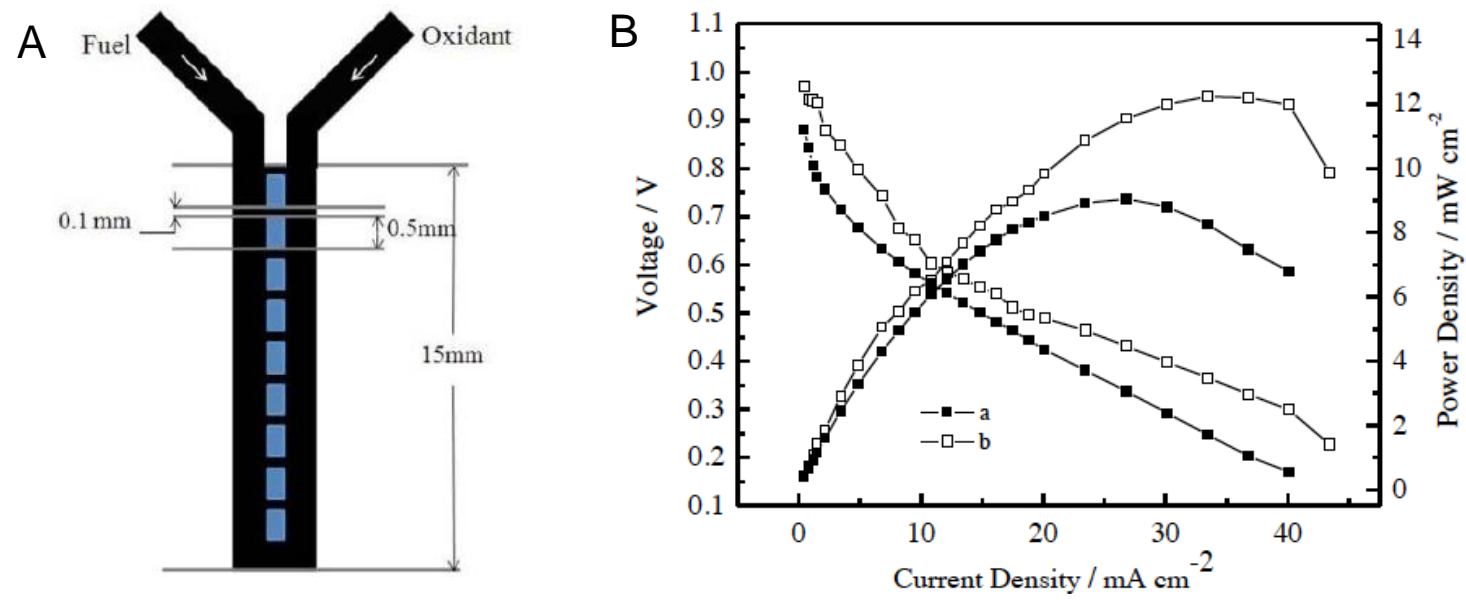

Fig. 3. (A) Schematic drawing of the ladder microchannel structure and (B) Polarization curves of the microfluidic $\mathrm{MeOH} / \mathrm{H}_{2} \mathrm{O}_{2}$ fuel cell with (a) normal shaped microchannel and (b) ladder-shaped microchannel at $25{ }^{\circ} \mathrm{C}$. The flow rates of anolyte and catholyte were $0.5 \mathrm{~mL} \mathrm{~min}^{-1}{ }^{11}$ 
cells were similar level of that of $\mathrm{H}_{2} \mathrm{O}_{2} / \mathrm{H}_{2} \mathrm{O}_{2}$ fuel cell, although the oxidation potentials of formic acid $\left(\mathrm{CO}_{2}+2 \mathrm{H}^{+}+2 \mathrm{e}^{-}=\mathrm{HCOOH} ; E^{0}=-0.199 \mathrm{~V}\right.$ vs $\left.\mathrm{NHE}\right)$ and methanol $\left(\mathrm{CO}_{2}+2 \mathrm{H}_{2}+4 \mathrm{e}^{-}=\mathrm{CH}_{3} \mathrm{OH}+\mathrm{H}_{2} \mathrm{O} ; E^{\mathrm{o}}=0.03 \mathrm{~V}\right.$ vs NHE$)$ were negative compared with that of $\mathrm{H}_{2} \mathrm{O}_{2}\left(E^{\mathrm{o}}=0.682 \mathrm{~V}\right) .{ }^{10,11}$ These results indicate larger overpotentials are necessary for fuels oxidation at the anodes.

Several $\mathrm{NaBH}_{4}-\mathrm{H}_{2} \mathrm{O}_{2}$ fuel cells employed Pt supported on carbon as the cathode together with $\mathrm{Zn}, \mathrm{AuCo} / \mathrm{TiO}_{2}-\mathrm{NTs}, \mathrm{Ag}$ needles or $\mathrm{Pd}$ supported on carbon as an anode. ${ }^{13-17}$ High open circuit voltage of $3.0 \mathrm{~V}$ is predicted from negative oxidation potential of $\mathrm{BH}_{4}^{-}\left(\mathrm{BH}_{4}^{-}+8 \mathrm{OH}^{-}=\mathrm{BO}_{2}^{-}+6 \mathrm{H}_{2} \mathrm{O}+8 \mathrm{e}^{-} ; E^{\mathrm{o}}=-1.24 \mathrm{~V}\right.$ vs NHE$)$ and highly positive reduction potential of $\mathrm{H}_{2} \mathrm{O}_{2}\left(E^{\mathrm{o}}=1.76 \mathrm{~V}\right)$ under acidic conditions, which is higher than $1.23 \mathrm{~V}$ of $\mathrm{H}_{2} / \mathrm{O}_{2}$ fuel cells and $1.19 \mathrm{~V}$ of $\mathrm{MeOH} / \mathrm{O}_{2}$ fuel cells. ${ }^{18} \mathrm{~A}$ $\mathrm{NaBH}_{4} / \mathrm{H}_{2} \mathrm{O}_{2}$ fuel cell constructed with Pt supported on carbon as the cathode exhibited extremely high power density of $600 \mathrm{~mW} \mathrm{~cm}^{-2}$ with open circuit voltage of $1.3 \mathrm{~V}$ by supplying an aqueous solution containing $20 \% \mathrm{H}_{2} \mathrm{O}_{2}$ and $5 \%$ phosphate as catholyte and that containing $20 \% \mathrm{NaBH}_{4}$ and $1.8 \mathrm{M} \mathrm{NaOH}$ as anolyte (Fig. 4). ${ }^{18}$

A

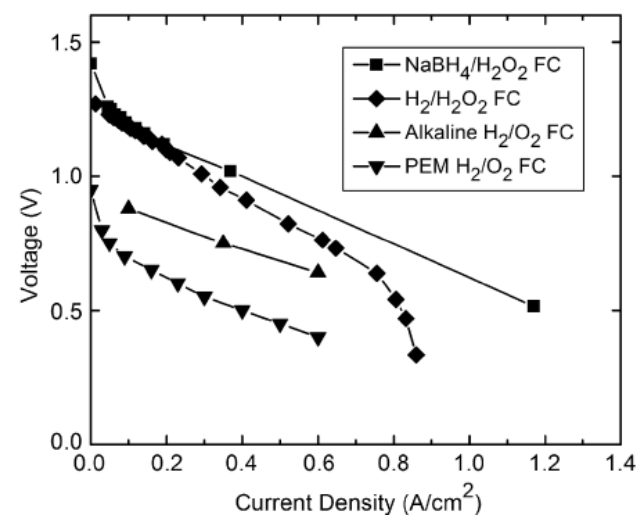

B

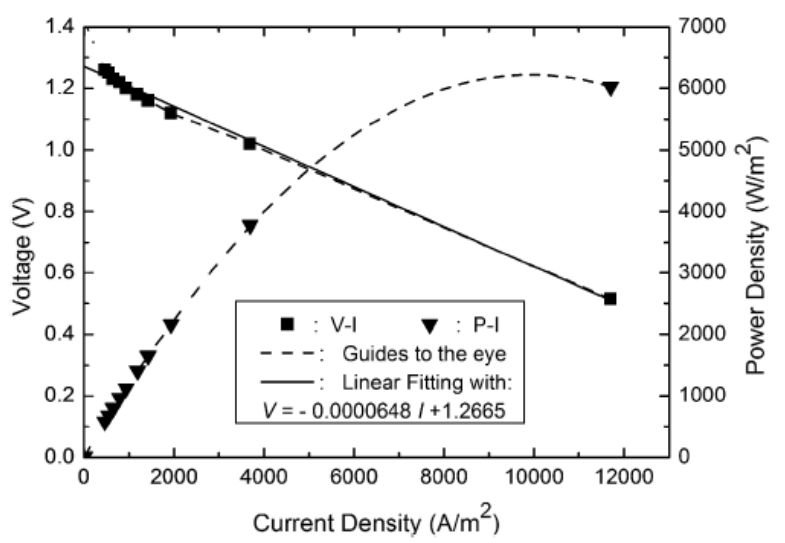

Fig. 4. (A) The $I-V$ characteristics of $\mathrm{NaBH}_{4} / \mathrm{H}_{2} \mathrm{O}_{2}, \mathrm{H}_{2} / \mathrm{H}_{2} \mathrm{O}_{2}$, alkaline $\mathrm{H}_{2} / \mathrm{O}_{2}$ and $\mathrm{H}_{2} / \mathrm{O}_{2}$ PEM fuel cells operating at room temperature, and ambient pressure. The curve for the $\mathrm{H}_{2} / \mathrm{H}_{2} \mathrm{O}_{2}$ fuel cell is tested with an acidic catholyte $(\mathrm{pH}$ 2). (B) Power density of the $\mathrm{NaBH}_{4} / \mathrm{H}_{2} \mathrm{O}_{2}$ fuel cell. ${ }^{18}$ 


\section{b. Au-Based Catalysts}

$\mathrm{Au}$ based catalysts are used as cathodes of $\mathrm{NaBH}_{4} / \mathrm{H}_{2} \mathrm{O}_{2}, \mathrm{~N}_{2} \mathrm{H}_{4} / \mathrm{H}_{2} \mathrm{O}_{2}$ and $\mathrm{Al} / \mathrm{H}_{2} \mathrm{O}_{2}$ fuel cells. $\mathrm{NaBH}_{4} / \mathrm{H}_{2} \mathrm{O}_{2}$ fuel cells using $\mathrm{Au}$ as cathodes exhibit high power density ranging from 100 to $400 \mathrm{~mW} \mathrm{~cm}^{-2}$ as well as those using Pt as cathodes. Not only high catalytic activity for $\mathrm{H}_{2} \mathrm{O}_{2}$ reduction but also low activity for $\mathrm{H}_{2} \mathrm{O}_{2}$ decomposition made $\mathrm{Au}$ as a suitable cathode for the $\mathrm{NaBH}_{4} / \mathrm{H}_{2} \mathrm{O}_{2}$ fuel cells, which was evidenced by catalysis examination of multiwall carbon nanotubes supporting $\mathrm{Rh}, \mathrm{Ru}, \mathrm{Pt}, \mathrm{Au}, \mathrm{Ag}, \mathrm{Pd}$, $\mathrm{Ni}$, and $\mathrm{Cu}$ for both $\mathrm{H}_{2} \mathrm{O}_{2}$ reduction and $\mathrm{H}_{2} \mathrm{O}_{2}$ decomposition. ${ }^{19}$

The anodic reaction of $\mathrm{Al} / \mathrm{H}_{2} \mathrm{O}_{2}$ fuel cells is as follows: $\mathrm{Al}+3 \mathrm{OH}^{-}=\mathrm{Al}(\mathrm{OH})_{3}+3 \mathrm{e}^{-}$; $E^{\mathrm{o}}=-2.30 \mathrm{~V}$, thus, the combination with the cathodic reaction $\left(\mathrm{HO}_{2}^{-}+\mathrm{H}_{2} \mathrm{O}+2 \mathrm{e}^{-}=\right.$ $\left.3 \mathrm{OH}^{-} ; E^{\mathrm{o}}=0.87 \mathrm{~V}\right)$ provides the overall voltage of $3.17 \mathrm{~V} \cdot{ }^{19}$ A simple flow-path $\mathrm{Al} / \mathrm{H}_{2} \mathrm{O}_{2}$ fuel cell using $\mathrm{Al}$ and $\mathrm{Au}$ plates as the anode and cathode, respectively, showed the maximum voltage around $1.4 \mathrm{~V}$ under the currents of $10^{-7}$ to $10^{-2} \mathrm{~A}$ in $\mathrm{KOH}$ solution (Fig. 5). ${ }^{20}$

(A)

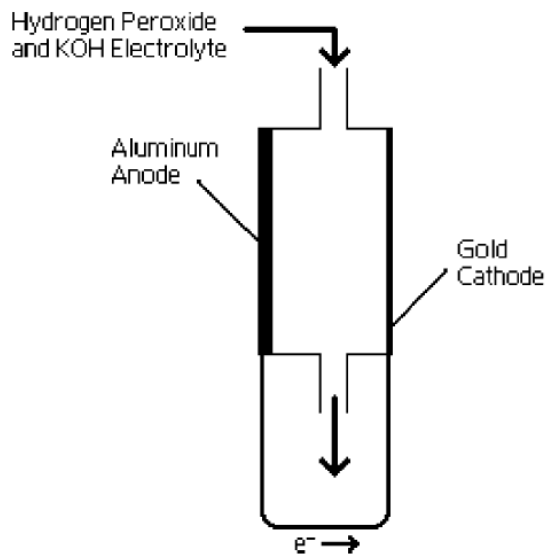

(B)

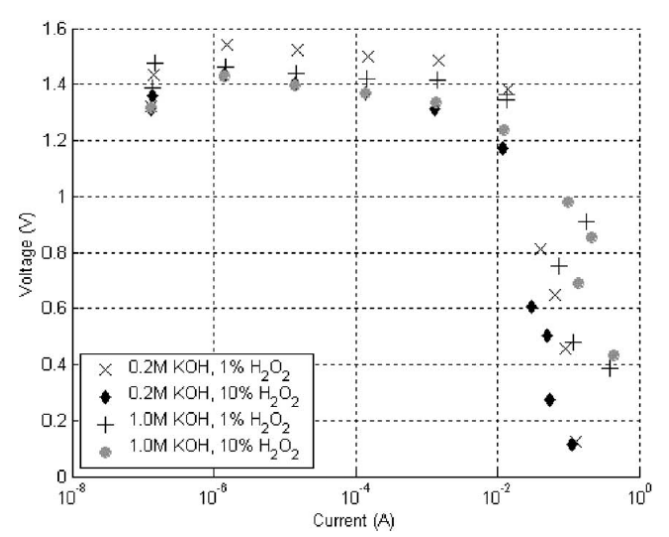

Fig. 5. (A) Single flow-path fuel-cell configuration and (B) voltage versus current graph for the concentration tests. ${ }^{20}$

$\mathrm{N}_{2} \mathrm{H}_{4}$ is an attractive fuel in $\mathrm{N}_{2} \mathrm{H}_{4} / \mathrm{O}_{2}$ fuel cells, because the expected open circuit potential of $\mathrm{N}_{2} \mathrm{H}_{4}\left(\mathrm{~N}_{2} \mathrm{H}_{4}+\mathrm{O}_{2}=\mathrm{N}_{2}+2 \mathrm{H}_{2} \mathrm{O} ; E^{\mathrm{o}}=1.56 \mathrm{~V}\right.$ vs NHE$)$ is higher than that of $\mathrm{H}_{2} / \mathrm{O}_{2}$ fuel cells $(1.23 \mathrm{~V}) .{ }^{21} \mathrm{~N}_{2} \mathrm{H}_{4} / \mathrm{H}_{2} \mathrm{O}_{2}$ fuel cells are expected to produce higher open 
circuit voltage of $2.1 \mathrm{~V}$ under acidic conditions. A two-compartment $\mathrm{N}_{2} \mathrm{H}_{4} / \mathrm{H}_{2} \mathrm{O}_{2}$ fuel cell was constructed with nanoporous gold for both anode and cathode using an aqueous solution containing $\mathrm{N}_{2} \mathrm{H}_{4}$ and $\mathrm{NaOH}$ and an aqueous solution containing $\mathrm{H}_{2} \mathrm{O}_{2}$ and $\mathrm{H}_{2} \mathrm{SO}_{4}$ as the anolyte and catholyte, respectively. ${ }^{22}$ The performance of the $\mathrm{N}_{2} \mathrm{H}_{4} / \mathrm{H}_{2} \mathrm{O}_{2}$ fuel cell highly depends on the concentrations of electrolytes in the anolyte and catholyte (Table 1). ${ }^{22}$ The highest open circuit voltage of $1.02 \mathrm{~V}$ and maximum power density of $99 \mathrm{~mW} \mathrm{~cm}^{-2}$ were achieved by using an aqueous solution containing $4 \mathrm{M}$ $\mathrm{NaOH}$ and $10 \mathrm{wt} \% \mathrm{~N}_{2} \mathrm{H}_{4}$ as an anolyte and that containing $0.5 \mathrm{M} \mathrm{H}_{2} \mathrm{SO}_{4}$ and $20 \% \mathrm{H}_{2} \mathrm{O}_{2}$ as a catholyte at $60{ }^{\circ} \mathrm{C} .{ }^{22}$ The power density and open circuit voltage increased to 195.4 $\mathrm{mW} \mathrm{cm}{ }^{-2}$ and $1.21 \mathrm{~V}$, respectively, by increasing the operation temperature to $80{ }^{\circ} \mathrm{C}^{22}$ Cell performance of the $\mathrm{N}_{2} \mathrm{H}_{4} / \mathrm{H}_{2} \mathrm{O}_{2}$ fuel cell employing nanoporous gold for both anode and cathode was superior to that employing $\mathrm{Pt} / \mathrm{C}$ in terms of power density and open circuit voltage. ${ }^{22}$ A $\mathrm{N}_{2} \mathrm{H}_{4} / \mathrm{H}_{2} \mathrm{O}_{2}$ fuel cell employing a $\mathrm{Pt}$ based anode and a $\mathrm{Au} / \mathrm{C}$ cathode resulted in further improvement in both open circuit voltage $(1.75 \mathrm{~V})$ and power density $\left(1.02 \mathrm{~W} \mathrm{~cm}^{-2}\right)$ as shown in Fig. $6 .^{23}$ The superior performance of the $\mathrm{NaBH}_{4} / \mathrm{H}_{2} \mathrm{O}_{2}$ fuel cell using the $\mathrm{Au}$ cathode compared with that using the Pt cathode resulted from suppression of $\mathrm{H}_{2} \mathrm{O}_{2}$ decomposition on the Au electrode.

Table 1. Performance of $\mathrm{N}_{2} \mathrm{H}_{4} / \mathrm{H}_{2} \mathrm{O}_{2}$ fuel cells with various concentrations of electrolyte $^{22}$

\begin{tabular}{lllc}
\hline Anolyte & \multicolumn{1}{c}{ Catholyte } & OCV/V & $\mathrm{MPD} / \mathrm{mW} \mathrm{cm}^{-2}$ \\
\hline $4 \mathrm{M} \mathrm{NaOH}$ & $0.05 \mathrm{M} \mathrm{H}_{2} \mathrm{SO}_{4}$ & 0.249 & - \\
$4 \mathrm{M} \mathrm{NaOH}$ & $0.5 \mathrm{M} \mathrm{H}_{2} \mathrm{SO}_{4}$ & 0.489 & - \\
$4 \mathrm{M} \mathrm{NaOH}$ & $1 \mathrm{M} \mathrm{H}_{2} \mathrm{SO}_{4}$ & 0.665 & - \\
$0.4 \mathrm{M} \mathrm{NaOH}$ & $0.5 \mathrm{M} \mathrm{H}_{2} \mathrm{SO}_{4}$ & 0.334 & - \\
$0.04 \mathrm{M} \mathrm{NaOH}$ & $0.5 \mathrm{M} \mathrm{H}_{2} \mathrm{SO}_{4}$ & 0.188 & - \\
$0.04 \mathrm{M} \mathrm{NaOH}+10 \% \mathrm{~N}_{2} \mathrm{H}_{4}$ & $0.5 \mathrm{M} \mathrm{H}_{2} \mathrm{SO}_{4}+20 \% \mathrm{H}_{2} \mathrm{O}_{2}$ & 0.531 & 16.44 \\
$0.4 \mathrm{M} \mathrm{NaOH}+10 \% \mathrm{~N}_{2} \mathrm{H}_{4}$ & $0.5 \mathrm{M} \mathrm{H}_{2} \mathrm{SO}_{4}+20 \% \mathrm{H}_{2} \mathrm{O}_{2}$ & 0.750 & 23.08 \\
$4 \mathrm{M} \mathrm{NaOH}+10 \% \mathrm{~N}_{2} \mathrm{H}_{4}$ & $0.5 \mathrm{M} \mathrm{H}_{2} \mathrm{SO}_{4}+20 \% \mathrm{H}_{2} \mathrm{O}_{2}$ & 1.025 & 99.47 \\
$4 \mathrm{M} \mathrm{NaOH}+10 \% \mathrm{~N}_{2} \mathrm{H}_{4}$ & $0.05 \mathrm{M} \mathrm{H}_{2} \mathrm{SO}_{4}+20 \% \mathrm{H}_{2} \mathrm{O}_{2}$ & 0.630 & 63.63 \\
\hline
\end{tabular}

OCV: open circuit voltage, MPD: maximum power density 

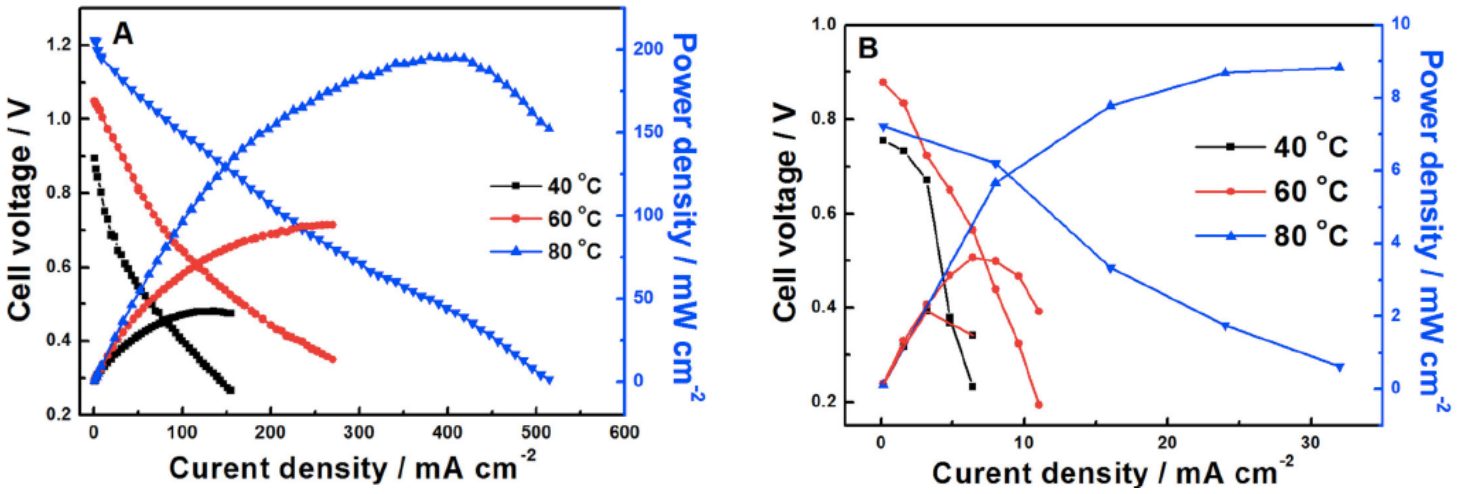

Fig. 6. Performance of a $\mathrm{N}_{2} \mathrm{H}_{4} / \mathrm{H}_{2} \mathrm{O}_{2}$ fuel cell at various temperatures with (A) nanoporous gold and (B) Pt/C as the catalysts for both anode and cathode, an aqueous solution of $4 \mathrm{M} \mathrm{NaOH}+10 \mathrm{wt} \% \mathrm{~N}_{2} \mathrm{H}_{4}$ as the anolyte and that of $0.5 \mathrm{M} \mathrm{H}_{2} \mathrm{SO}_{4}+20 \mathrm{wt} \%$ $\mathrm{H}_{2} \mathrm{O}_{2}$ as the catholyte. The flow rates of the anolyte and catholyte were 1.4 and $4.2 \mathrm{~mL}$ $\min ^{-1}$, respectively. ${ }^{22}$

\section{c. Pd-Based Catalysts}

$\mathrm{Pd}$ cathodes were utilized in $\mathrm{NaBH}_{4} / \mathrm{H}_{2} \mathrm{O}_{2}, \mathrm{H}_{2} \mathrm{O}_{2} / \mathrm{H}_{2} \mathrm{O}_{2}, \mathrm{Al} / \mathrm{H}_{2} \mathrm{O}_{2}$ or $\mathrm{Mg} / \mathrm{H}_{2} \mathrm{O}_{2}$, $\mathrm{HCOOH} / \mathrm{H}_{2} \mathrm{O}_{2}$ and urea/ $\mathrm{H}_{2} \mathrm{O}_{2}$ fuel cells. ${ }^{10,24-29}$

A $\mathrm{H}_{2} \mathrm{O}_{2} / \mathrm{H}_{2} \mathrm{O}_{2}$ fuel cell utilizing dendric Pd supported on carbon fiber cloth for both anode and cathode exhibited power density of 14.3 and $58.4 \mathrm{~mW}$ at 20 and $60{ }^{\circ} \mathrm{C}$, respectively (Fig. 7). ${ }^{25,26}$ The power density of the $\mathrm{H}_{2} \mathrm{O}_{2} / \mathrm{H}_{2} \mathrm{O}_{2}$ fuel cell was improved by replacing the dendric $\mathrm{Pd}$ supported on carbon anode with various types of $\mathrm{Ni}$ electrodes. ${ }^{27-29}$ Especially, employment of $\mathrm{Ni}$ nanowire arrays as the anode resulted in the highest power density of $48.7 \mathrm{~mW} \mathrm{~cm}^{-2}$ at $20{ }^{\circ} \mathrm{C}^{29}$ Also, utilization of Ni supported on carbon fiber cloth (CFC) as the anode of a $\mathrm{H}_{2} \mathrm{O}_{2} / \mathrm{H}_{2} \mathrm{O}_{2}$ fuel cell resulted in $53.8 \mathrm{~mW}$ $\mathrm{cm}^{-2}$ at $50{ }^{\circ} \mathrm{C} .{ }^{28}$

Pd-Ir alloy is used as cathodes of $\mathrm{Al} / \mathrm{H}_{2} \mathrm{O}_{2}$ and $\mathrm{Mg} / \mathrm{H}_{2} \mathrm{O}_{2}$ fuel cells. ${ }^{30,31}$ An $\mathrm{Al} / \mathrm{H}_{2} \mathrm{O}_{2}$ fuel cell using $\mathrm{Pd}-\mathrm{Ir}$ as the cathode operated in an aqueous solution containing 3.0 M NaOH, $0.5 \mathrm{M} \mathrm{H}_{2} \mathrm{O}_{2}$ and $40 \mathrm{~g} \mathrm{~L}^{-1}$ sea salt at $55{ }^{\circ} \mathrm{C}$. The $\mathrm{Al} / \mathrm{H}_{2} \mathrm{O}_{2}$ fuel cell exhibited the open circuit voltage of $1.8 \mathrm{~V}$ and the maximum current density of $400 \mathrm{~mA}$ $\mathrm{cm}^{-2} .{ }^{31}$ The same Pd-Ir cathode was also used in $\mathrm{Mg}-\mathrm{H}_{2} \mathrm{O}_{2}$ fuel cells. The oxidation 
A

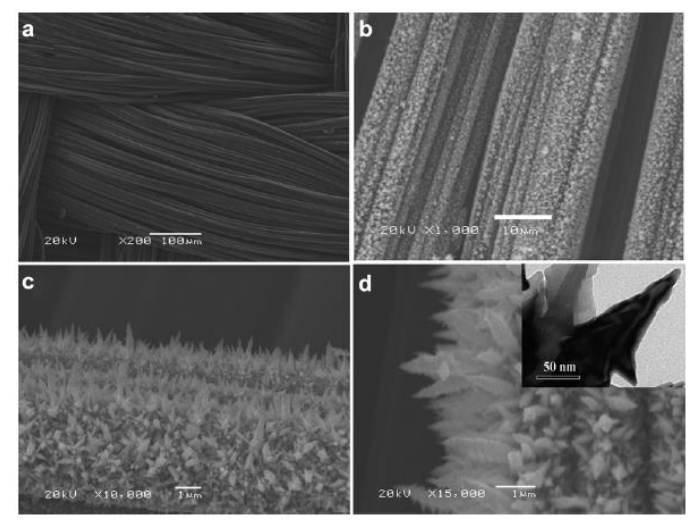

B

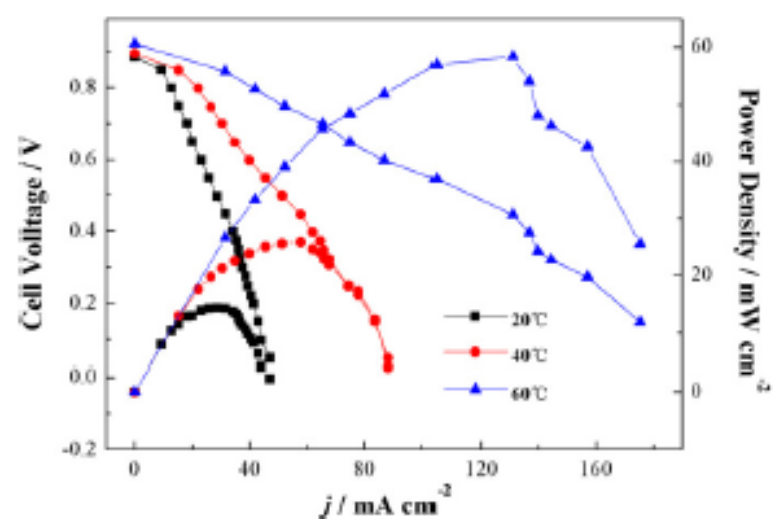

Fig. 7. (A) SEM images of CFC (a) and Pd/CFC (b, c and d) and TEM image of Pd (inset of d) and (B) Effect of operating temperature on the cell performance. Anolyte: 4.0 M KOH + 1.0 M H $\mathrm{M} \mathrm{O}_{2}$. Catholyte: $2.0 \mathrm{M} \mathrm{H}_{2} \mathrm{SO}_{4}+2.0 \mathrm{M} \mathrm{H}_{2} \mathrm{O}_{2}$. Flow rate: $10 \mathrm{~mL}$ $\left.\min ^{-1}\right) .{ }^{25,26}$

potential of $\mathrm{Mg}\left(\mathrm{Mg}=\mathrm{Mg}^{2+}+2 \mathrm{e}^{-} ; E^{\mathrm{o}}=-2.37 \mathrm{~V}\right.$ vs NHE$)$ lower than that of $\mathrm{Al}\left(\mathrm{Al}^{3+}+\right.$ $3 \mathrm{e}^{-}=\mathrm{Al} ; E^{\mathrm{o}}=-1.68 \mathrm{~V}$ vs NHE) theoretically allows to construct high voltage fuel cells with open circuit voltage of $4.15 \mathrm{~V} .{ }^{32-34}$ A two-compartment $\mathrm{Mg} / \mathrm{H}_{2} \mathrm{O}_{2}$ fuel cell employing a $\mathrm{Mg}$ wafer and Ir-Pd deposited on a carbon microfiber array as the anode and cathode, respectively, operated in an aqueous solution containing $\mathrm{NaCl}\left(40 \mathrm{~g} \mathrm{~L}^{-1}\right)$ for the anode and that containing $\mathrm{H}_{2} \mathrm{O}_{2}, 0.2 \mathrm{M} \mathrm{H}_{2} \mathrm{SO}_{4}$ and $\mathrm{NaCl}\left(40 \mathrm{~g} \mathrm{~L}^{-1}\right)$ for the cathode (Fig. 8). ${ }^{34}$ The output potential of the $\mathrm{Mg} / \mathrm{H}_{2} \mathrm{O}_{2}$ fuel cell at low current density was $\sim 2.0 \mathrm{~V}$, and the maximum power density reached $84 \mathrm{~mW} \mathrm{~cm}^{-2} .{ }^{34}$ The power density can be increased to $200 \mathrm{~mW} \mathrm{~cm} \mathrm{~cm}^{-2}$ by increasing the operation temperature and concentration of $\mathrm{H}_{2} \mathrm{O}_{2}$ in the catholyte, however, significant $\mathrm{H}_{2} \mathrm{O}_{2}$ decomposition was observed on the cathode. ${ }^{35}$ 
A

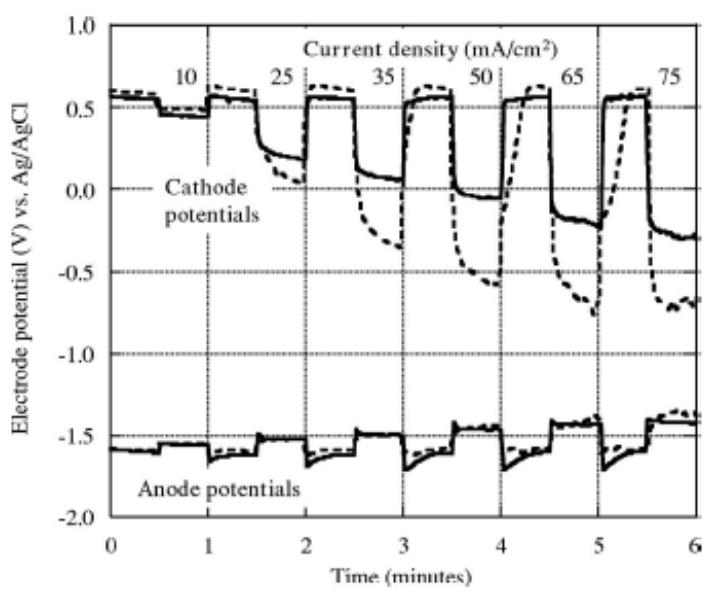

B

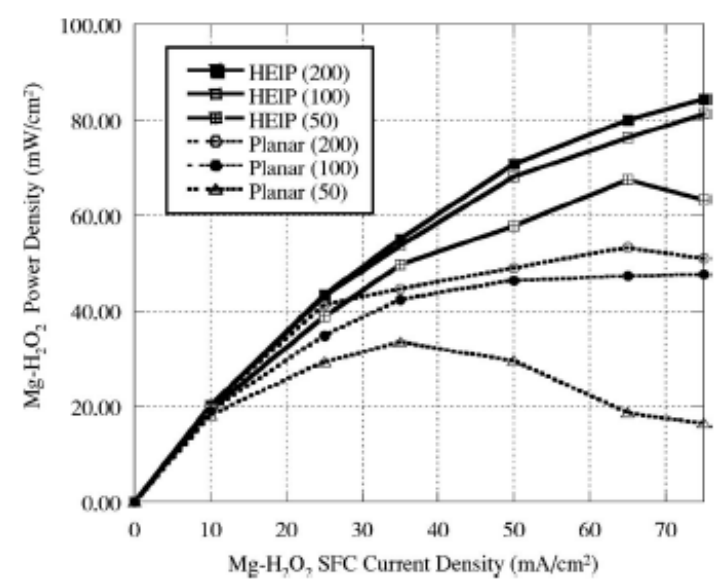

Fig. 8. (A) $\mathrm{Mg}-\mathrm{H}_{2} \mathrm{O}_{2}$ fuel cell cathode and anode potentials at various current densities: [ - : SFC with Ir-Pd deposited on a carbon microfiber array (HEIP) cathode] and (- - -: SFC with a planar cathode) ${ }^{34}$ (B) Power density of $\mathrm{Mg}-\mathrm{H}_{2} \mathrm{O}_{2}$ fuel cell with HEIP or planar cathodes. Catholyte flow rates in $\mathrm{mL} \mathrm{min}^{-1}$ are given in parentheses. Anode flow rates were $200 \mathrm{~mL} \mathrm{~min}^{-1}{ }^{34}$

\section{d. Ag-Based Catalysts}

One-compartment fuel cells utilizing $\mathrm{H}_{2} \mathrm{O}_{2}$ as both fuel and oxidant were constructed with $\mathrm{Ag}$ and $\mathrm{Au}$ plates as cathode and anode, respectively. ${ }^{36}$ Such a cell configuration is possible by employing selective electrodes for $\mathrm{H}_{2} \mathrm{O}_{2}$ reduction and oxidation. Measurements of cyclic voltammograms of $\mathrm{H}_{2} \mathrm{O}_{2}$ on $\mathrm{Au}, \mathrm{Ag}, \mathrm{Pt}$, and $\mathrm{Pd}$ electrodes indicated both oxidation and reduction currents increased by the addition of $\mathrm{H}_{2} \mathrm{O}_{2}{ }^{36}$ The onset potential for $\mathrm{H}_{2} \mathrm{O}_{2}$ reduction on a $\mathrm{Ag}$ electrode (ca. $-0.05 \mathrm{~V}$, Fig. 9A) was the highest among the electrodes although far below the thermodynamic value $(0.73 \mathrm{~V}) .{ }^{36}$ The onset potential for $\mathrm{H}_{2} \mathrm{O}_{2}$ oxidation on a Au electrode was lower than the onset potential for $\mathrm{H}_{2} \mathrm{O}_{2}$ reduction on a $\mathrm{Ag}$ electrode (Fig. 9B). This indicates that $\mathrm{H}_{2} \mathrm{O}_{2}$ oxidation by the $\mathrm{Au}$ electrode with $\mathrm{H}_{2} \mathrm{O}_{2}$ reduction by the $\mathrm{Ag}$ electrode can produce electric power. A one-compartment $\mathrm{H}_{2} \mathrm{O}_{2}$ fuel cell using $\mathrm{Ag}$ and $\mathrm{Au}$ plates as cathode and anode operated in an aqueous solution containing $1 \mathrm{M} \mathrm{NaOH}$ and $300 \mathrm{mM} \mathrm{H}_{2} \mathrm{O}_{2}$ successfully generated electrical power with the maximum current density of $2.9 \mathrm{~mA}$ $\mathrm{cm}^{-2}$ (Fig. 10). ${ }^{36}$ 

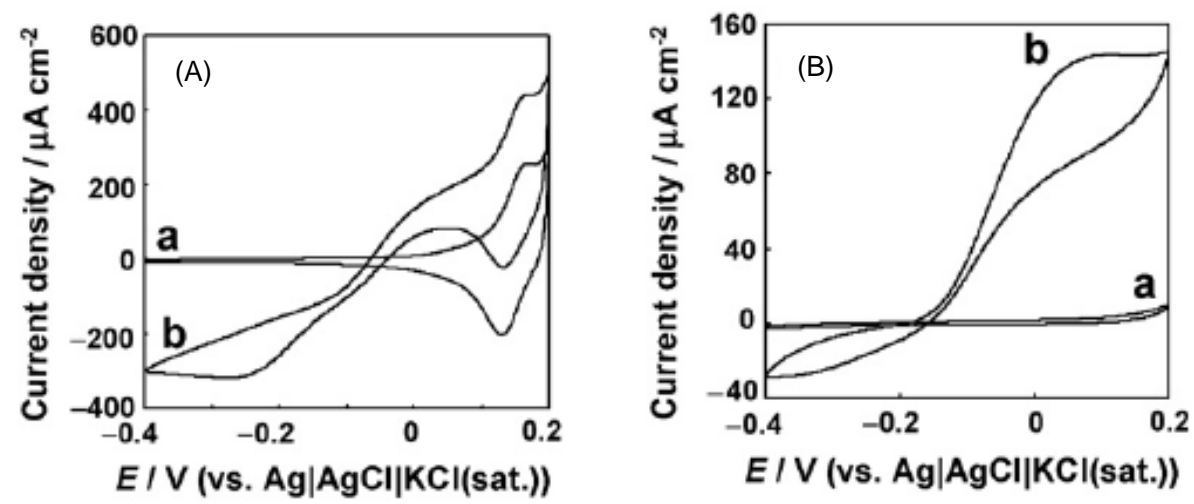

Fig. 9. Cyclic voltammograms of $\mathrm{H}_{2} \mathrm{O}_{2}$ on (A) $\mathrm{Ag}$ and (B) $\mathrm{Au}$ electrodes. Lines (a) and (b) indicate voltammograms in the absence and presence of $\mathrm{H}_{2} \mathrm{O}_{2}$, respectively. The measurements were performed in a $1 \mathrm{M} \mathrm{NaOH}$ solution under a nitrogen atmosphere. The concentration of $\mathrm{H}_{2} \mathrm{O}_{2}$ was fixed at $3 \mathrm{mM}^{36}$
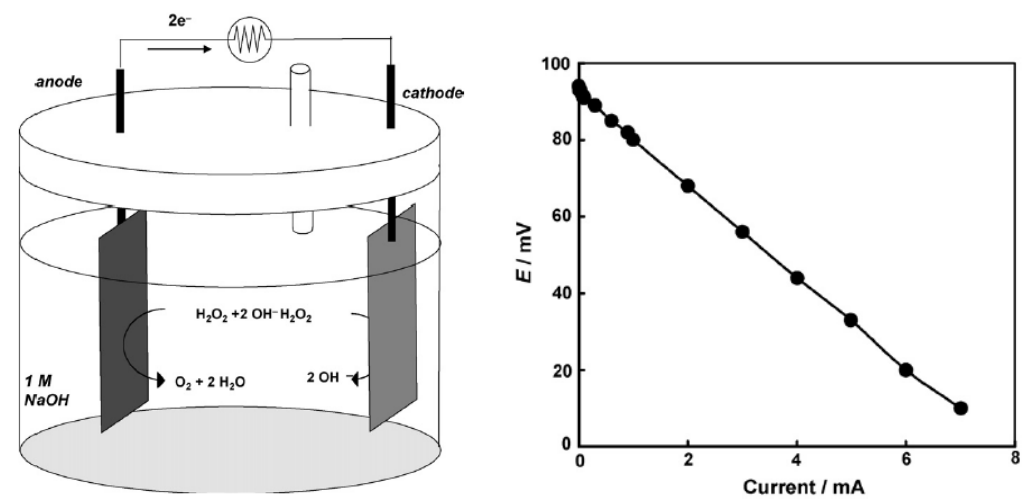

Fig. 10. $I^{-} V$ curve of a one-compartment $\mathrm{H}_{2} \mathrm{O}_{2}$ fuel cell with $\mathrm{Au}$ anode-Ag cathode. Performance tests were conducted in $1 \mathrm{M} \mathrm{NaOH}$ solution containing $300 \mathrm{mM} \mathrm{H}_{2} \mathrm{O}_{2}$. The electrode surface areas are fixed at $2.4 \mathrm{~cm}^{2}{ }^{36}$

The one-compartment fuel cells utilizing $\mathrm{H}_{2} \mathrm{O}_{2}$ were also constructed with $\mathrm{Ag}-\mathrm{Pb}$ alloy nanoparticles supported on a glassy carbon electrode as the cathode and Au plates as the anode. ${ }^{37}$ Alloy formation of $\mathrm{Ag}$ with $\mathrm{Pb}$, which was confirmed by TEM observations and X-ray diffraction patterns, reduced the overpotential of $\mathrm{H}_{2} \mathrm{O}_{2}$ reduction, resulting in increasing power density by 5 times (Fig. 11). ${ }^{37}$

$\mathrm{Al} / \mathrm{H}_{2} \mathrm{O}_{2}$ fuel cells were constructed with a cathode composed of $\mathrm{Ag}$ electrodeposited on $\mathrm{Ni}$ foam. ${ }^{38}$ The performance of an $\mathrm{Al} / \mathrm{H}_{2} \mathrm{O}_{2}$ fuel cell using the $\mathrm{Ag} / \mathrm{Ni}$ cathode was examined with an solution containing $0.5 \mathrm{M} \mathrm{H}_{2} \mathrm{O}_{2}, 2.0 \mathrm{M} \mathrm{NaOH}$ and 
(A)
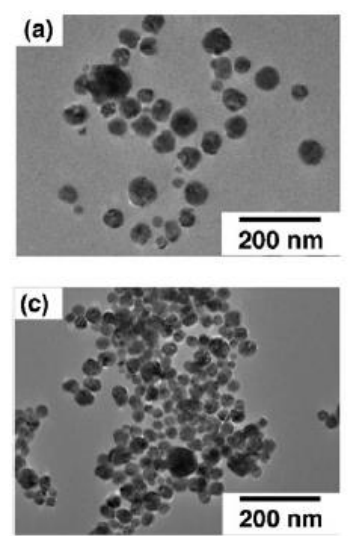
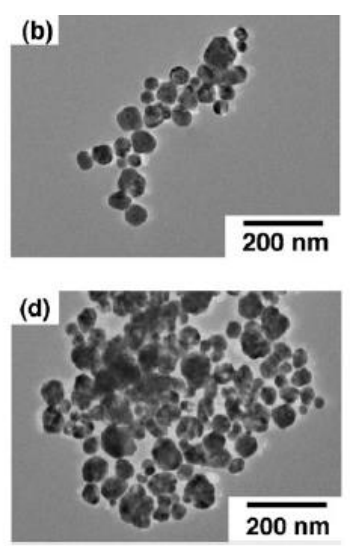

(B)

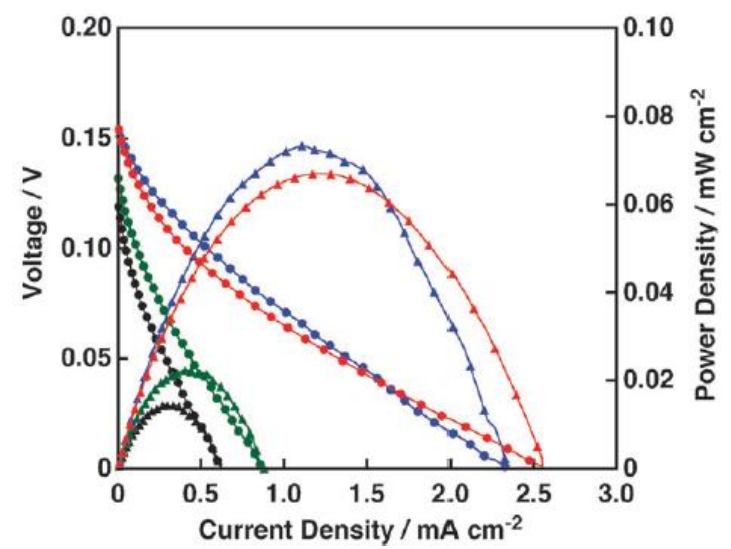

Fig. 11. (A) TEM images of $\mathrm{Ag}$ or $\mathrm{Ag}-\mathrm{Pb}$ alloy nanoparticles. (a) Ag nanoparticles, (b) $\mathrm{Ag}-\mathrm{Pb}$ alloy $(\mathrm{Ag}: \mathrm{Pb}=9: 1)$, (c) Ag-Pb alloy (7:3) and (d) $\mathrm{Ag}-\mathrm{Pb}$ alloy $(\mathrm{Ag}: \mathrm{Pb}=$ 6 : 4). (B) $I-V$ and $I-P$ curves of a one-compartment $\mathrm{H}_{2} \mathrm{O}_{2}$ fuel cell with $\mathrm{Ag}$ or $\mathrm{Ag}-\mathrm{Pb}$ alloy cathode. (Au anode. $1 \mathrm{M} \mathrm{NaOH}, 300 \mathrm{mM} \mathrm{H}_{2} \mathrm{O}_{2}$. Black: $\mathrm{Ag}$, green: $\mathrm{Ag}: \mathrm{Pb}=6: 4$, red: $\mathrm{Ag}: \mathrm{Pb}=7: 3$ and blue: $\mathrm{Ag}: \mathrm{Pb}=9: 1){ }^{37}$

$40 \mathrm{~g} \mathrm{~L}^{-1} \mathrm{NaCl}$ at $45^{\circ} \mathrm{C}$. The maximum power density of the $\mathrm{Al} / \mathrm{H}_{2} \mathrm{O}_{2}$ fuel cell reached to $450 \mathrm{mWcm}^{-2} .38$ When simple Ag mesh was employed as the cathode of the $\mathrm{Al} / \mathrm{H}_{2} \mathrm{O}_{2}$ fuel cell instead of $\mathrm{Ag} / \mathrm{Ni}$ cathode, the performance was significantly lowered. Cell voltage measured at $250 \mathrm{mAcm}^{-2}$ for the $\mathrm{Al} / \mathrm{H}_{2} \mathrm{O}_{2}$ fuel cell containing $\mathrm{Ag}$ catalyzed cathode was as much as $500 \mathrm{mV}$ higher than that of planar Ag mesh (Fig. 12). ${ }^{38}$ Thus, Ag-Ni interaction is beneficial to improve the catalysis for $\mathrm{H}_{2} \mathrm{O}_{2}$ reduction. ${ }^{38}$

(A)

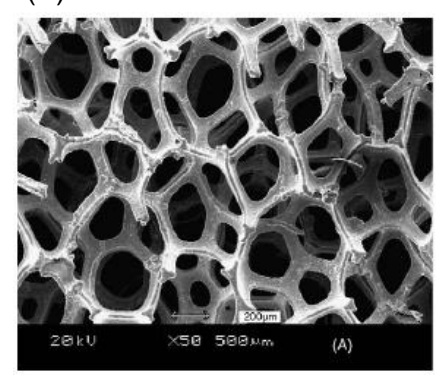

(B)

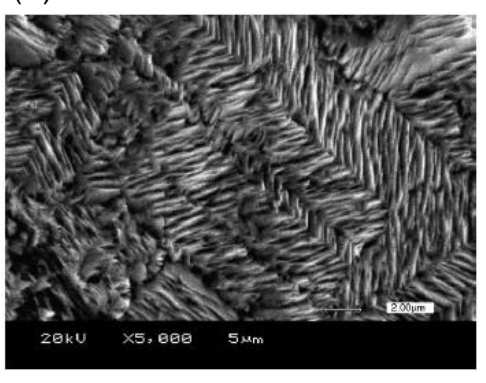

(C)

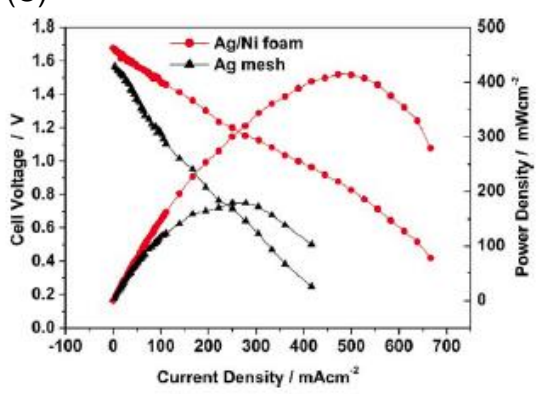

Fig. 12. SEM images of (A) Ni foam and (B) Ag/Ni foam. (C) Performance comparison of $\mathrm{Al} / \mathrm{H}_{2} \mathrm{O}_{2}$ fuel cells with $\mathrm{Ag} / \mathrm{Ni}$ and $\mathrm{Ag}$ mesh cathodes at $45{ }^{\circ} \mathrm{C}$. Anode: $99.996 \%$ aluminum; electrolyte: $0.5 \mathrm{M} \mathrm{H}_{2} \mathrm{O}_{2}, 2.0 \mathrm{M} \mathrm{NaOH}$ and $40 \mathrm{~g} \mathrm{~L}^{-1} \mathrm{NaCl}^{38}$ 
Catalysis of $\mathrm{Ag} / \mathrm{Ni}$ electrode was further enhanced by combined with Pd metal in $\mathrm{Mg}-\mathrm{H}_{2} \mathrm{O}_{2}$ fuel cells. ${ }^{39} \mathrm{Pd}$ was electrodeposited on $\mathrm{Ag} / \mathrm{Ni}$ foam (Fig. 13). The content of deposited $\mathrm{Pd}$ was nearly double of Ag metal on the $\mathrm{Ni}$ form determined by EDS analysis. ${ }^{39}$ Cathodic polarization behavior of $\mathrm{Ag} / \mathrm{Ni}$ and $\mathrm{Pd}-\mathrm{Ag} / \mathrm{Ni}$ was compared at 20 and $50{ }^{\circ} \mathrm{C}$. In both cases, electrode performance for $\mathrm{H}_{2} \mathrm{O}_{2}$ reduction was improved at higher temperature and $\mathrm{Pd}-\mathrm{Ag} / \mathrm{Ni}$ showed superior activity to $\mathrm{Ag} / \mathrm{Ni}$. As expected, the performance of $\mathrm{Mg} / \mathrm{H}_{2} \mathrm{O}_{2}$ fuel cell constructed with $\mathrm{Pd}-\mathrm{Ag} / \mathrm{Ni}$ was better than that with $\mathrm{Ag} / \mathrm{Ni}$ at the same operation temperature. ${ }^{39}$ At $50{ }^{\circ} \mathrm{C}$, the maximum power density of the fuel cell using $\mathrm{Pd}-\mathrm{Ag} / \mathrm{Ni}$ reached $140 \mathrm{~mW} \mathrm{~cm}^{-2}$, on the other hand, that of $\mathrm{Ag} / \mathrm{Ni}$ remained at $110 \mathrm{~mW} \mathrm{~cm}^{-2}$ (Fig. 14). ${ }^{39}$

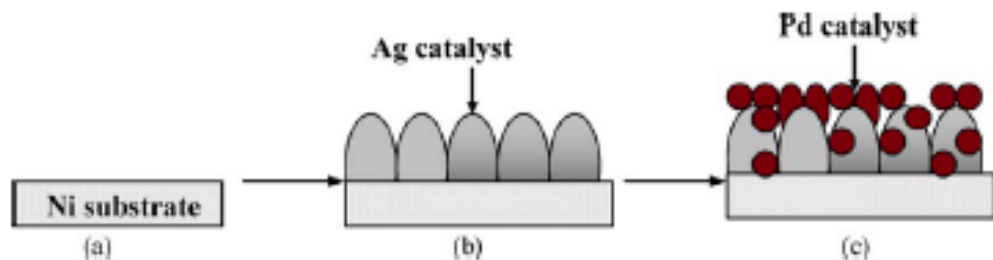

Fig. 13. Schematic of the preparation method of Pd-Ag catalyzed Ni foam electrode. (a) $\mathrm{Ni}$ foam, (b) $\mathrm{Ag} / \mathrm{Ni}$ cathode and (c) $\mathrm{Pd}-\mathrm{Ag} / \mathrm{Ni}$ cathode. ${ }^{39}$

(A)

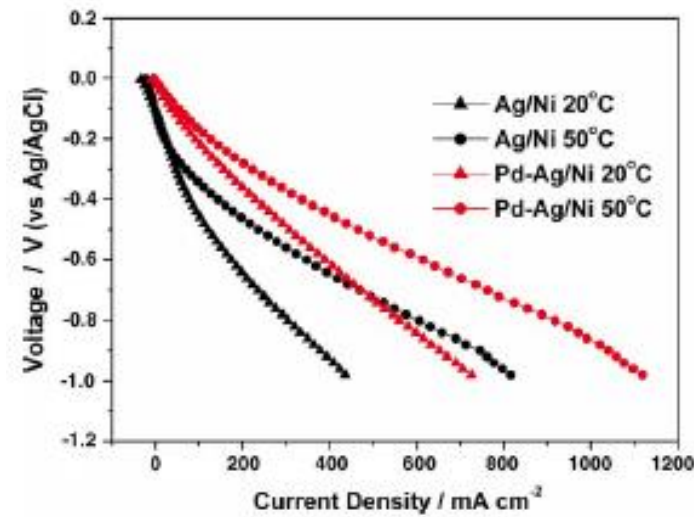

(B)

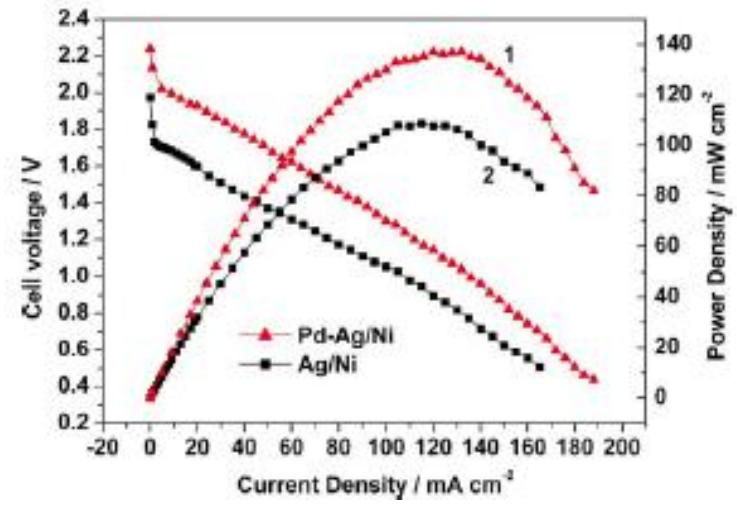

Fig. 14. (A) Polarization curves for $\mathrm{Ag} / \mathrm{Ni}$ and $\mathrm{Pd}-\mathrm{Ag} / \mathrm{Ni}$ cathodes at 20 and $50{ }^{\circ} \mathrm{C}$. Electrolyte: $0.5 \mathrm{M} \mathrm{H}_{2} \mathrm{O}_{2}, 0.1 \mathrm{M} \mathrm{H}_{2} \mathrm{SO}_{4}$ and $40 \mathrm{~g} \mathrm{~L}^{-1} \mathrm{NaCl}$. (B) Performance comparison of $\mathrm{Mg} / \mathrm{H}_{2} \mathrm{O}_{2}$ fuel cell with different cathodes at $50{ }^{\circ} \mathrm{C}$. Anode: $99.96 \% \mathrm{Mg}$. Cathode: (1) $\mathrm{Pd}-\mathrm{Ag} / \mathrm{Ni}$ and (2) Ag/Ni. Anolyte: $40 \mathrm{~g} \mathrm{~L}^{-1} \mathrm{NaCl}, 200 \mathrm{ml} \mathrm{min}^{-1}$. Catholyte: $0.5 \mathrm{M} \mathrm{H}_{2} \mathrm{O}_{2}$, $0.1 \mathrm{M} \mathrm{H}_{2} \mathrm{SO}_{4}$ and $40 \mathrm{~g} \mathrm{~L}^{-1}, \mathrm{NaCl}, 100 \mathrm{ml} \mathrm{min}^{-1}$. 99 


\section{e. Ni-Based Catalysts}

Rolled up Ni form was used as cathode of a $\mathrm{Li} / \mathrm{H}_{2} \mathrm{O}_{2}$ semi-fuel cell with high stability longer than $800 \mathrm{~h}$, which is suitable for electric vehicles applications (Fig. 15). ${ }^{40}$ High output voltage of $4.83 \mathrm{~V}$ was expected for the cell because of very negative potential on $\mathrm{Li}$ ionization $\left(\mathrm{Li}=\mathrm{Li}^{+}+\mathrm{e}^{-}, E^{\mathrm{o}}=-3.05 \mathrm{~V}\right.$ vs NHE$)$ and very positive potential of $\mathrm{H}_{2} \mathrm{O}_{2}$ reduction $\left(\mathrm{H}_{2} \mathrm{O}_{2}+2 \mathrm{H}^{+}+2 \mathrm{e}^{-}=2 \mathrm{H}_{2} \mathrm{O}, E^{\mathrm{o}}=1.78 \mathrm{~V}\right.$ vs NHE). ${ }^{40}$ However, the obtained discharge voltage was $2.7 \mathrm{~V}$, which is comparable to that of $\mathrm{Li}_{-} \mathrm{O}_{2}$ batteries. ${ }^{40}$ A reason for the low voltage seemed to be undesired reaction on cathode as evidenced by lower open circuit potential of the cathode $(\sim 0.52 \mathrm{~V})$, implying side reactions owing to $\mathrm{O}_{2}$ contamination $\left(\mathrm{O}_{2}+2 \mathrm{H}^{+}+2 \mathrm{e}^{-}=\mathrm{H}_{2} \mathrm{O}_{2}, E^{\mathrm{o}}=0.695 \mathrm{~V}\right.$ vs $\mathrm{NHE}$ or $\mathrm{O}_{2}+2 \mathrm{H}_{2} \mathrm{O}+4 \mathrm{e}^{-}=$ $\left.4 \mathrm{OH}^{-}, E^{\mathrm{o}}=0.401 \mathrm{~V}\right) .{ }^{40}$ More appropriate cathode suitable for $\mathrm{H}_{2} \mathrm{O}_{2}$ reduction without $\mathrm{H}_{2} \mathrm{O}_{2}$ decomposition should be chosen for this battery system.

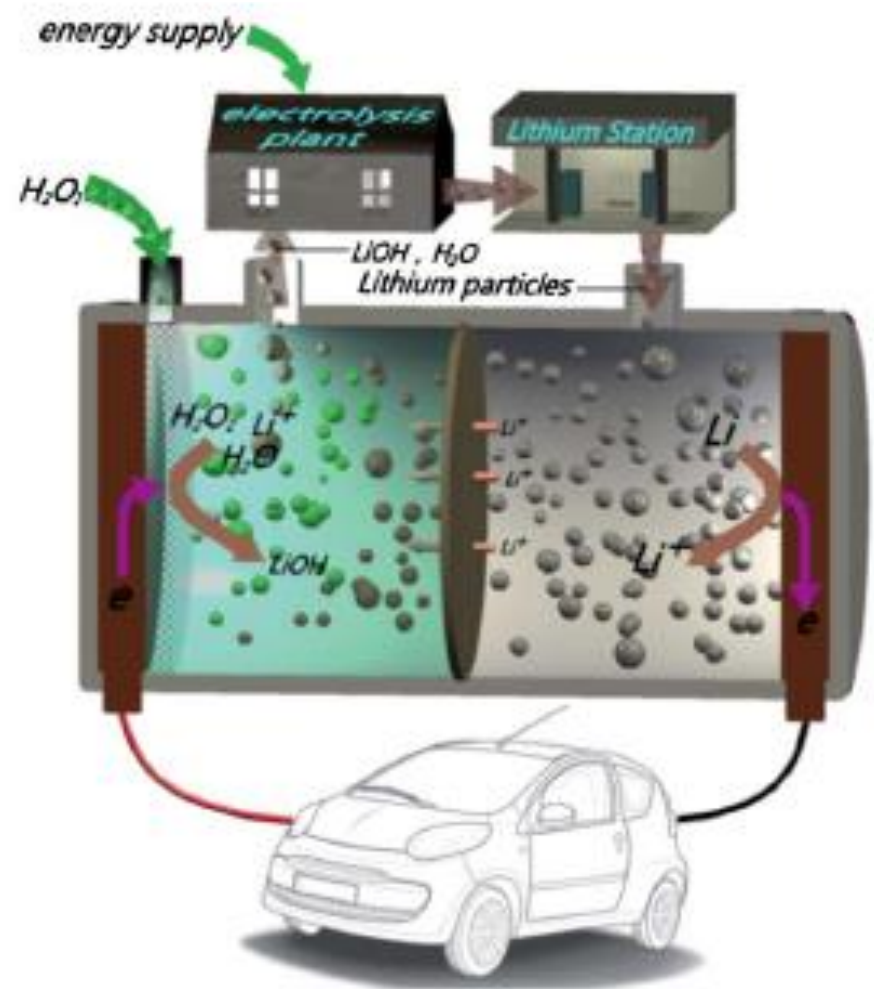

Fig. 15. A concept image for $\mathrm{Li} / \mathrm{H}_{2} \mathrm{O}_{2}$ semi-fuel cell with a lithium recycle system for electric vehicles propulsion. Cars get refuelled in lithium stations; the only emission is $\mathrm{LiOH}$, which can be used to fabricate metallic Li for fuel in plants. ${ }^{40}$ 


\section{Metal-Oxide Catalysts}

\section{a. Co-Based Oxides}

Assembly of $\mathrm{Co}_{3} \mathrm{O}_{4}$ nanowires supported on $\mathrm{Ni}$-form has been utilized as the cathode of an $\mathrm{Al} / \mathrm{H}_{2} \mathrm{O}_{2}$ fuel cell (Fig. 16). ${ }^{41}$ The $\mathrm{Al}$ anode was supplied 3.0 M KOH solution and the catholyte contained $3.0 \mathrm{M} \mathrm{KOH}$ and $0.2-1.0 \mathrm{M} \mathrm{H}_{2} \mathrm{O}_{2}{ }^{41}$ Cell performance with $0.4 \mathrm{M} \mathrm{H} \mathrm{H}_{2} \mathrm{O}_{2}$ catholyte improved by increasing the operation temperature, where the peak power density was $85 \mathrm{~mW} \mathrm{~cm} \mathrm{~cm}^{-2}$ at room temperature increased to $137 \mathrm{~mW} \mathrm{~cm}{ }^{-2}$ at $65{ }^{\circ} \mathrm{C}$ (Fig. 17). ${ }^{41} \mathrm{La}_{0.6} \mathrm{Ca}_{0.4} \mathrm{CoO}_{3}$ prepared by calcination at $650{ }^{\circ} \mathrm{C}$ has been employed instead of $\mathrm{Co}_{3} \mathrm{O}_{4} / \mathrm{Ni}$ as the cathode in the $\mathrm{Al} / \mathrm{H}_{2} \mathrm{O}_{2}$ fuel cell. The power density of the cell exceeded $200 \mathrm{~mW} \mathrm{~cm}^{-2}$ at room temperature (Fig. $18) .^{42}$
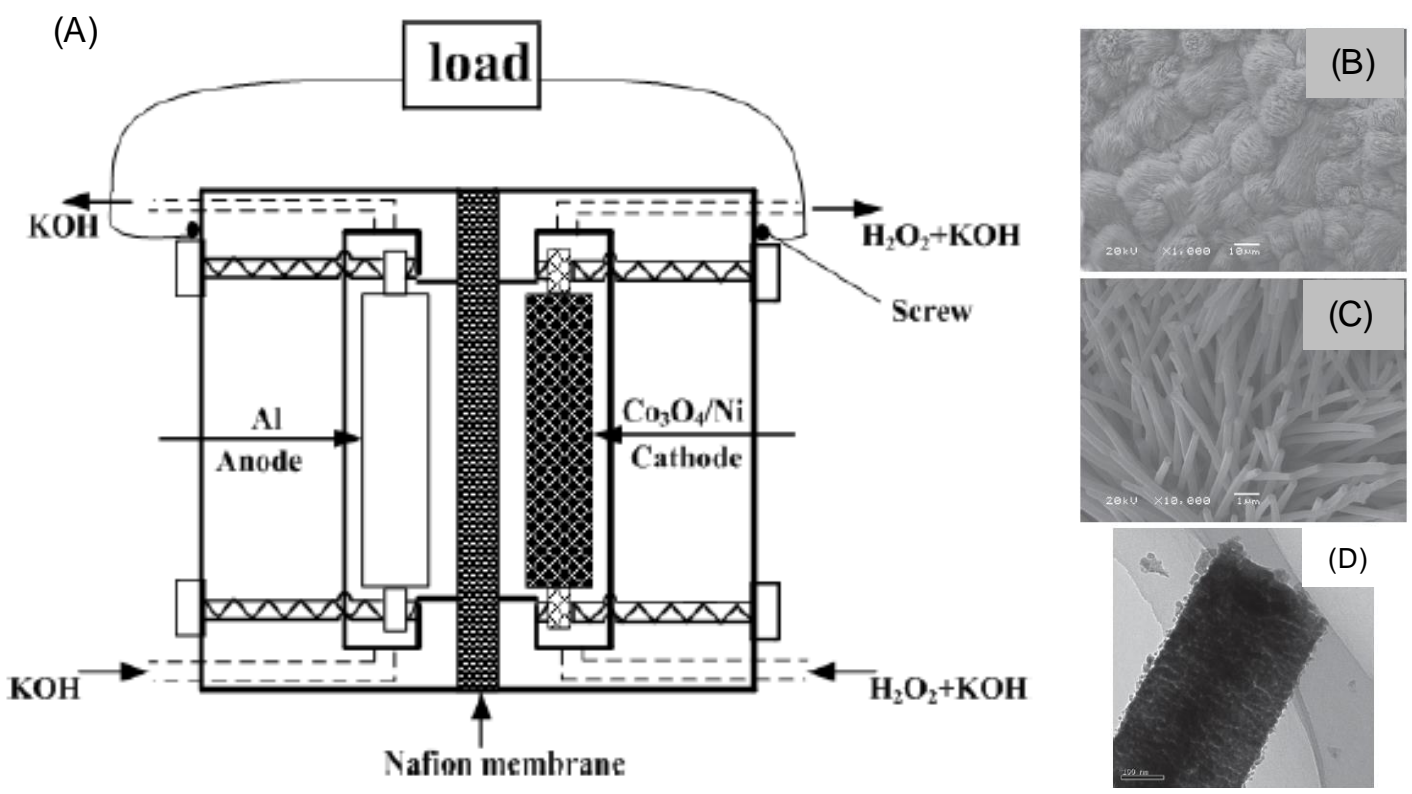

Fig. 16. (A) A schematic representation of the $\mathrm{Al} / \mathrm{H}_{2} \mathrm{O}_{2}$ fuel cell configuration (B, C) SEM images of the $\mathrm{Co}_{3} \mathrm{O}_{4} / \mathrm{Ni}$ cathode and (D) the TEM image of a single $\mathrm{Co}_{3} \mathrm{O}_{4}$ nanowire..$^{41}$ 


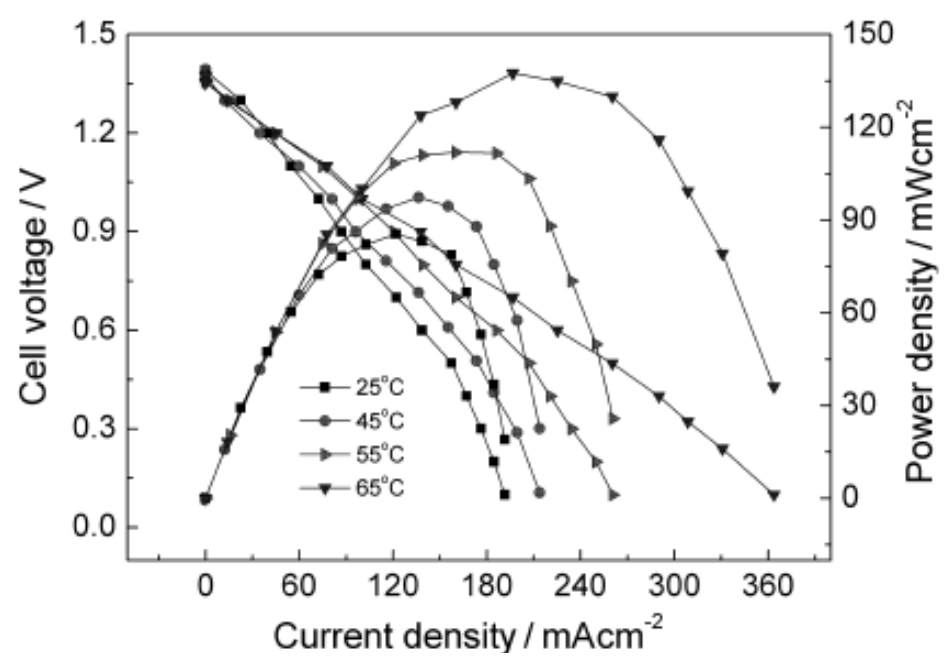

Fig. 17. Effects of the operation temperature on the $\mathrm{Al} / \mathrm{H}_{2} \mathrm{O}_{2}$ fuel cell performance. Anolyte: $3.0 \mathrm{M} \mathrm{KOH}$. Catholyte: $3.0 \mathrm{M} \mathrm{KOH}+0.4 \mathrm{M} \mathrm{H}_{2} \mathrm{O}_{2}$. Flow rate: $80 \mathrm{~mL} \mathrm{~min}{ }^{-1}{ }^{41}$

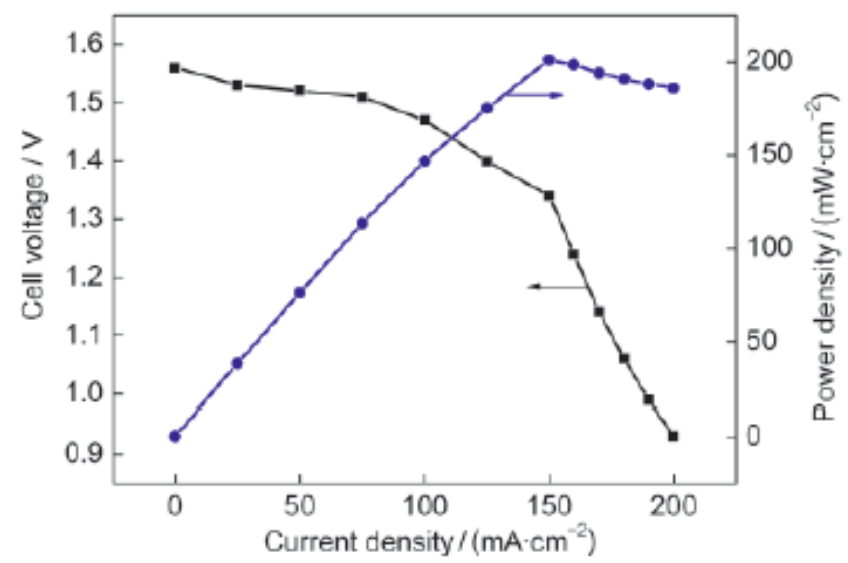

Fig.18. Performance of the $\mathrm{Al} / \mathrm{H}_{2} \mathrm{O}_{2}$ fuel cell with $\mathrm{La}_{0.6} \mathrm{Ca}_{0.4} \mathrm{CaO}_{3}$ cathode. Anolyte: 3.0 $\mathrm{M} \mathrm{KOH}$ at a flow rate of $80 \mathrm{~cm}^{3} \cdot \mathrm{min}^{-1}$; catholyte: $3.0 \mathrm{M} \mathrm{KOH}+0.4 \mathrm{M} \mathrm{H}_{2} \mathrm{O}_{2}$; operation temperature: room temperature. ${ }^{42}$

\section{b. Mn Oxide}

Mn-based perovskite, $\mathrm{La}_{0.7} \mathrm{Sr}_{0.3} \mathrm{MnO}_{3-\delta}$, was used as a cathode for constructing $\mathrm{NaBH}_{4} / \mathrm{H}_{2} \mathrm{O}_{2}$ fuel cells with a $\mathrm{Pt}$ mesh as an anode. ${ }^{43}$ Catalytic performance of $\mathrm{La}_{0.7} \mathrm{Sr}_{0.3} \mathrm{MnO}_{3-\delta}$ for $\mathrm{H}_{2} \mathrm{O}_{2}$ reduction was compared with Co-based perovskite chosen 
from $\mathrm{LaCoO}_{3-\delta}, \quad \mathrm{La}_{0.84} \mathrm{Sr}_{0.16} \mathrm{CoO}_{3-\delta}$ and $\left(\mathrm{La}_{0.8} \mathrm{Sr}_{0.2}\right)\left(\mathrm{Fe}_{0.8} \mathrm{Co}_{0.2}\right) \mathrm{O}_{3-\delta .}{ }^{43}$ Electrochemical measurements of an electrode modified with a perovskite were performed in a solution containing 0.4 $\mathrm{M} \mathrm{H}_{2} \mathrm{O}_{2}$ and $2 \mathrm{M} \mathrm{NaOH}$ (Fig. 19). ${ }^{43}$ Among the electrodes tested,

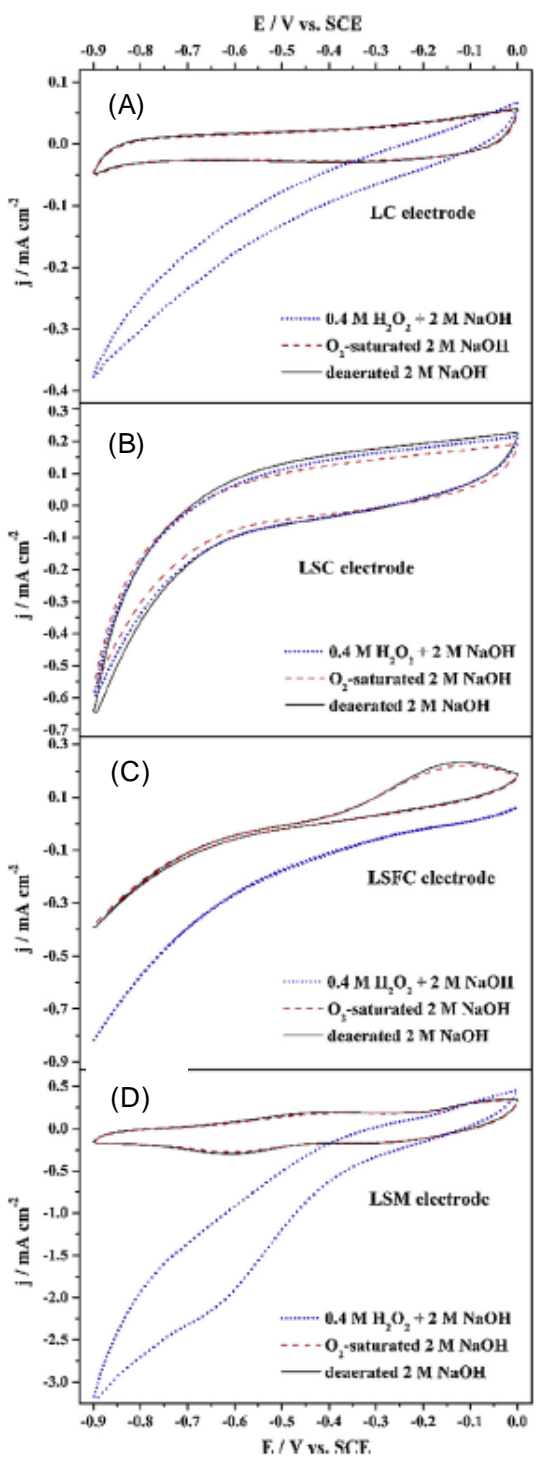

Fig. 19. Cyclic voltammograms of $\mathrm{H}_{2} \mathrm{O}_{2}$ on a perovskite cathode $\left[(\mathrm{A}) \mathrm{LaCoO}_{3-\delta}\right.$, , (B) $\mathrm{La}_{0.84} \mathrm{Sr}_{0.16} \mathrm{CoO}_{3-\delta}$, (C) $\left(\mathrm{La}_{0.8} \mathrm{Sr}_{0.2}\right)\left(\mathrm{Fe}_{0.8} \mathrm{Co}_{0.2}\right) \mathrm{O}_{3-\delta}$ and (D) $\left.\mathrm{La}_{0.7} \mathrm{Sr}_{0.3} \mathrm{MnO}_{3-\delta}\right]$ in $2 \mathrm{M}$ $\mathrm{NaOH}$ at $25{ }^{\circ} \mathrm{C}$. Scan rate: $25 \mathrm{mVs}^{-1} .{ }^{43}$

$\mathrm{La}_{0.7} \mathrm{Sr}_{0.3} \mathrm{MnO}_{3-\delta}$ exhibited the highest catalytic activity for $\mathrm{H}_{2} \mathrm{O}_{2}$ reduction. ${ }^{43}$ Thus, an $\mathrm{NaBH}_{4} / \mathrm{H}_{2} \mathrm{O}_{2}$ fuel cell was constructed with a Pt mesh and $\mathrm{La}_{0.7} \mathrm{Sr}_{0.3} \mathrm{MnO}_{3-\delta}$ as an anode and cathode, respectively. ${ }^{43}$ The cell performance measured at the temperatures ranging 
from 25 to $45{ }^{\circ} \mathrm{C}$ indicated that power density increased in accordance with the increase of the operating temperature, although the cell performance at $25^{\circ} \mathrm{C}$ was inferior to that of a fuel cell using Pt cathode instead of $\mathrm{La}_{0.7} \mathrm{Sr}_{0.3} \mathrm{MnO}_{3-\delta}$ (Fig. 20). ${ }^{43}$

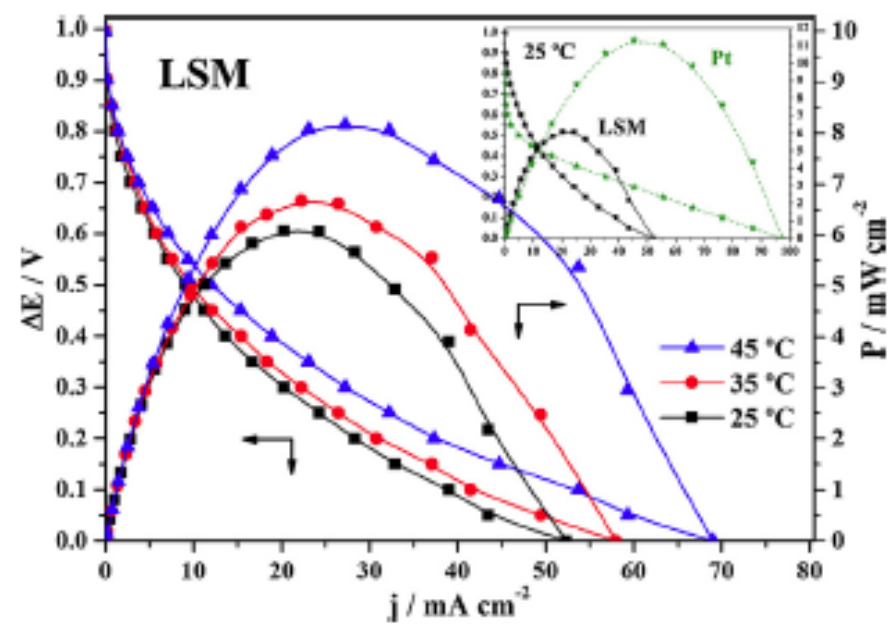

Fig. 20. Effect of temperature on the polarization behavior and corresponding peak power density curves for a DBPFC using LSM cathode. Inset shows direct comparison of the $\mathrm{La}_{0.7} \mathrm{Sr}_{0.3} \mathrm{MnO}_{3-\delta}(\mathrm{LSM})$ and Pt cathodes at $25{ }^{\circ} \mathrm{C} .{ }^{43}$

An $\mathrm{NaBH}_{4} / \mathrm{H}_{2} \mathrm{O}_{2}$ fuel cell employing $\mathrm{Pt} / \mathrm{C}$ and $\mathrm{MnO}_{2}$ as an anode and a cathode, respectively, showed high power density and open circuit voltage. Optimization of an electrolyte (Nafion membrane), operating temperature, concentrations of $\mathrm{NaBH}_{4}$ and $\mathrm{NaOH}$, and $\mathrm{H}_{2} \mathrm{O}_{2}$ resulted in increasing the power density to $130 \mathrm{~mW} \mathrm{~cm}{ }^{-2}$ under the conditions of Nafion $117,80{ }^{\circ} \mathrm{C}, 1.0 \mathrm{M} \mathrm{NaBH}_{4}, 2 \mathrm{M} \mathrm{NaOH}$, and $6.0 \mathrm{M} \mathrm{H}_{2} \mathrm{O}_{2}$ with the open circuit voltage of $1.3 \mathrm{~V}$ (Fig. 21). ${ }^{44}$

\section{Metal Complexes}

\section{a. Cyano-Bridged Complexes}

$\mathrm{H}_{2} \mathrm{O}_{2}$ reduction has been extensively studied for electrochemical sensors to detect $\mathrm{H}_{2} \mathrm{O}_{2}$ formation in biological cells. One of the most extensively studied material for this purpose is polymeric cyano-bridged metal complexes so called Prussian blue, $\mathrm{Fe}^{\mathrm{III}}\left[\mathrm{Fe}^{\mathrm{II}}(\mathrm{CN})_{6}\right]$, analogues (Fig. 22). ${ }^{45-71}$ 


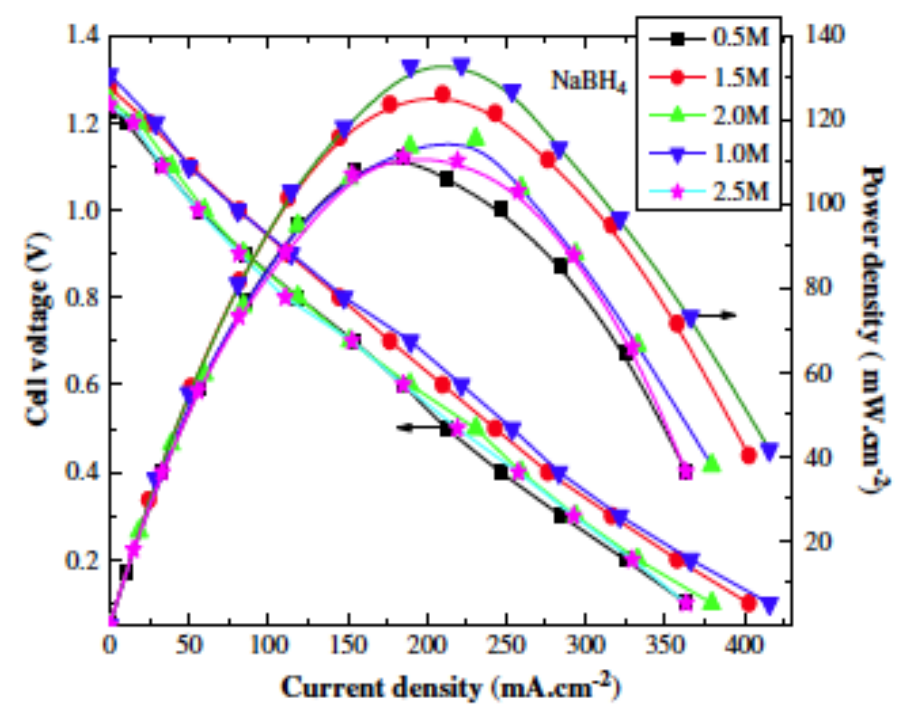

Fig. 21. Effect of $\mathrm{NaBH}_{4}$ concentration on the cell voltage and power density-current density curves collected from $\mathrm{NaBH}_{4} / \mathrm{H}_{2} \mathrm{O}_{2}$ fuel cell with a Nafion117 membrane at $80{ }^{\circ} \mathrm{C}$ : anode $\mathrm{Pt} / \mathrm{C}\left(4.0 \mathrm{mg} \mathrm{cm}^{-2}\right)$, cathode $\mathrm{MnO}_{2}\left(4.0 \mathrm{mg} \mathrm{cm}^{-2}\right), 2 \mathrm{M} \mathrm{NaOH}$ solution and $6.0 \mathrm{M} \mathrm{H}_{2} \mathrm{O}_{2}$ oxidant. $^{44}$

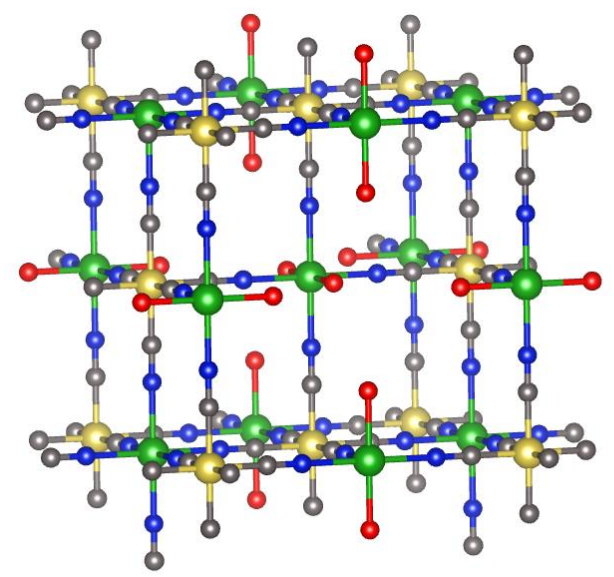

Fig. 22. A schematic drawing of a typical structure of Prussian blue

Prusssian-blue film electrodeposited on a Pt electrode was used as a cathode of direct borohydride fuel cells together with a Pt electrode as an anode. The fuel cells operated with an anolyte containing $\mathrm{NaBH}_{4}$ and $\mathrm{NaOH}$, and a catholyte containing $\mathrm{H}_{2} \mathrm{O}_{2}$ 
and $\mathrm{HCl}$. The fuel cell operating 1.0 $\mathrm{M} \mathrm{NaBH}_{4}$ and 4.0 $\mathrm{M} \mathrm{NaOH}$ as an anolyte and 5.0 $\mathrm{M} \mathrm{H}_{2} \mathrm{O}_{2}$ and $1.5 \mathrm{M} \mathrm{HCl}$ as catholyte exhibited the highest power density of $206 \mathrm{~mW}$ $\mathrm{cm}^{-2}$ at a cell voltage of $0.80 \mathrm{~V}$ and a current density of $257 \mathrm{~mA} \mathrm{~cm}^{-2}$ at $65{ }^{\circ} \mathrm{C}$ (Fig. 23). ${ }^{72}$

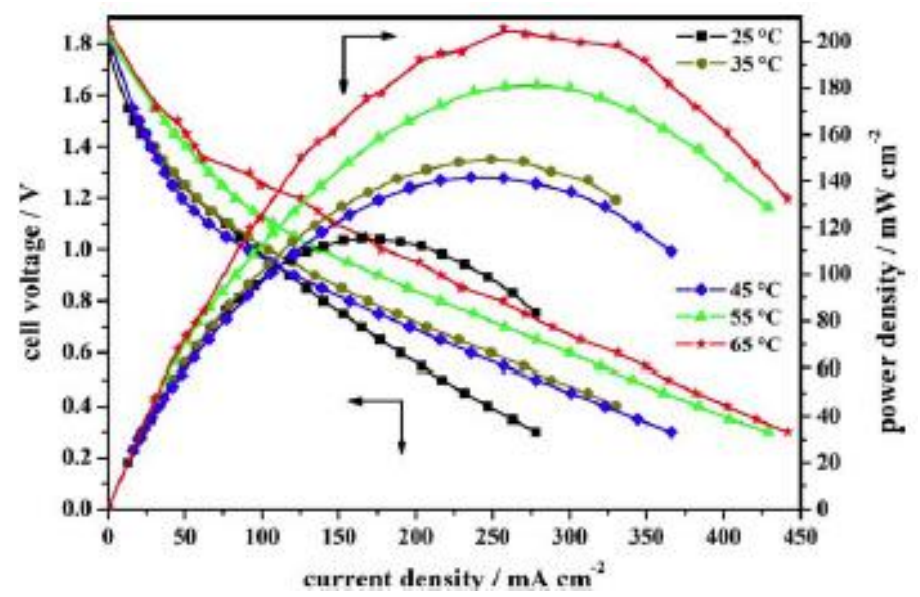

Fig. 23. Effect of the operation temperature on the current and power density of a $\mathrm{NaBH}_{4} / \mathrm{H}_{2} \mathrm{O}_{2}$ fuel cell using a prussian blue supportted on Pt as a cathode. Fuel: $1.0 \mathrm{M}$ $\mathrm{NaBH}_{4}+4.0 \mathrm{M} \mathrm{NaOH}$. Oxidant: $5.0 \mathrm{M} \mathrm{H}_{2} \mathrm{O}_{2}+1.5 \mathrm{M} \mathrm{HCl}^{72}$

Prusssian blue nanoparticles supported on a carbon paper $\left(10 \mathrm{mg} \mathrm{cm}^{-2}\right)$ by the spray drying method were used as a cathode of a one-compartment fuel cell using Ag or $\mathrm{Ni}$ as an anode. When the performance tests of the cells were examined with a solution containing $0.1 \mathrm{M} \mathrm{HCl}$ and $0.5 \mathrm{M} \mathrm{H}_{2} \mathrm{O}_{2}$, a maximum power densities were 0.8 and 1.55 $\mathrm{mW}$ with a silver anode and a $\mathrm{Ni}$ anode at $0.3 \mathrm{~V}$, respectively (Fig. 24). ${ }^{73}$

The catalytic activity of Prussian blue for $\mathrm{H}_{2} \mathrm{O}_{2}$ reduction can be improved by replacing $\mathrm{C}$-bound $\mathrm{Fe}$ ions with another metal ion such as $\mathrm{Co}(\mathrm{III})$ ion. $^{74}$ When $\mathrm{Fe}_{3}\left[\mathrm{Co}^{\mathrm{III}}(\mathrm{CN})_{6}\right]_{2}$ was employed as a cathode to construct a one-compartment fuel cell with a $\mathrm{Ni}$ anode, the maximum power densities, which were 0.17 and $1.2 \mathrm{~mW} \mathrm{~cm} \mathrm{~cm}^{-2}$ under the conditions of $\mathrm{pH} 3$ and 1, respectively, were double those of a fuel cell employing Prussian blue supported on a carbon paper $\left(2 \mathrm{mg} \mathrm{cm}^{-2}\right)$ as a cathode (Fig. 25). ${ }^{74}$ Inferior cell performance was observed when $\mathrm{Fe}_{3}\left[\mathrm{Ir}^{\mathrm{III}}(\mathrm{CN})_{6}\right]_{2}$ or $\mathrm{Fe}_{3}\left[\mathrm{Rh}^{\mathrm{III}}(\mathrm{CN})_{6}\right]_{2}$ was used as cathode instead of $\mathrm{Fe}_{3}\left[\mathrm{Co}^{\mathrm{III}}(\mathrm{CN})_{6}\right]_{2}$ although no significant change in the crystal structures was observed. ${ }^{74}$ 


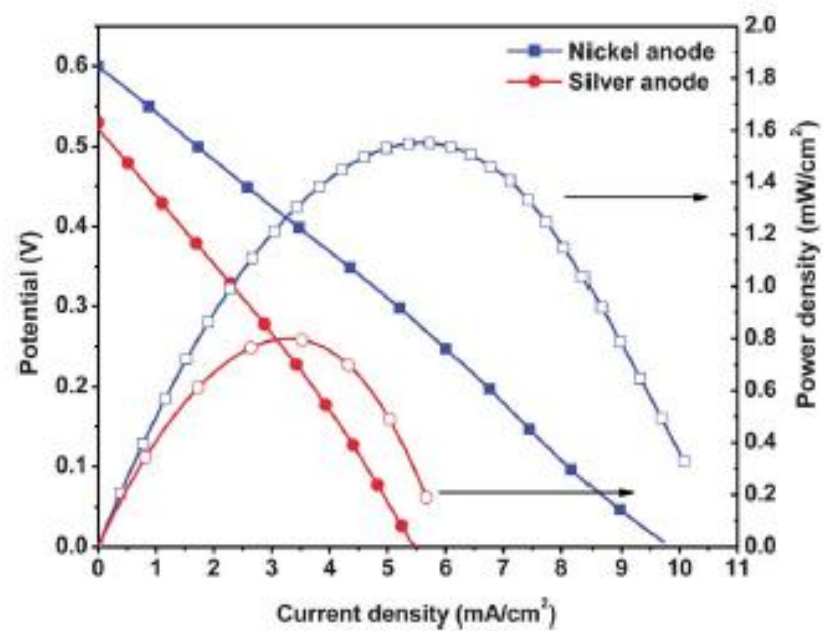

Fig. 24. Current-potential and current-power curves of the single compartment $\mathrm{H}_{2} \mathrm{O}_{2}$ fuel cell with nickel and silver anodes and unsupported PB coated on carbon paper as a cathode. Performance tests were carried out under acidic conditions using $0.1 \mathrm{M} \mathrm{HCl}$ and $0.5 \mathrm{M} \mathrm{H}_{2} \mathrm{O}_{2}{ }^{73}$
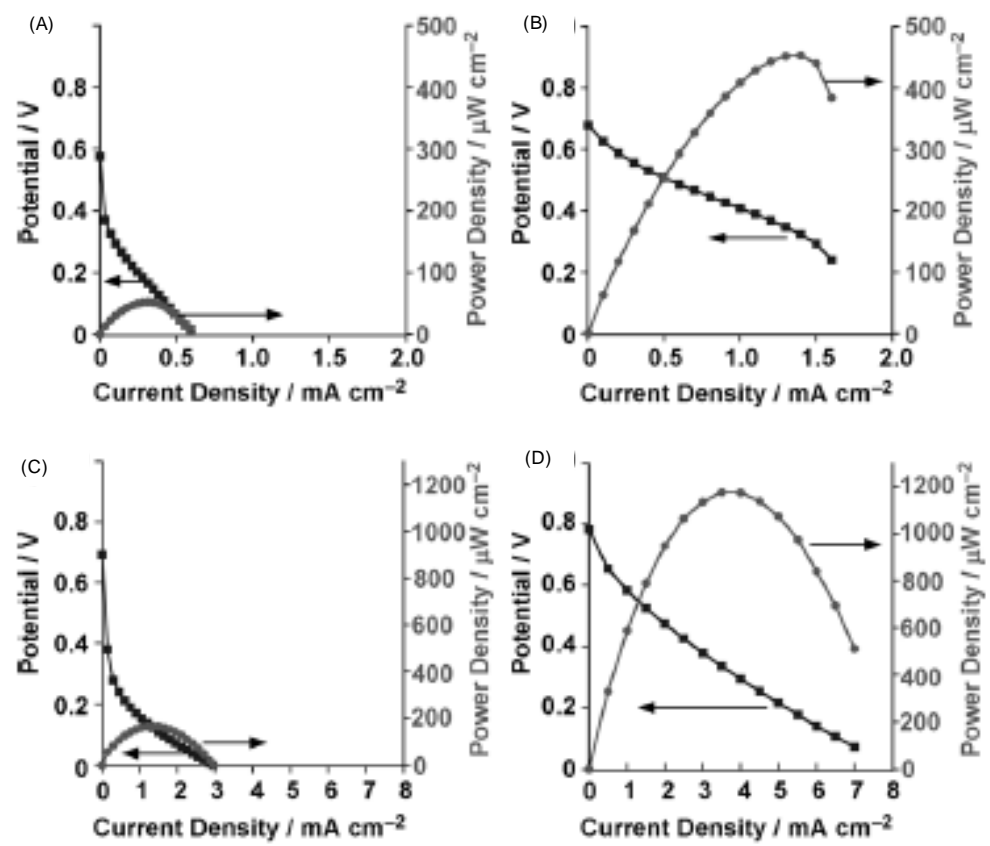

Fig. 25. $I-V$ (black) and $I-P$ (gray) curves of a one-compartment $\mathrm{H}_{2} \mathrm{O}_{2}$ fuel cell with a $\mathrm{Ni}$ anode and a carbon-cloth electrode that was modified with a polycyanide complex: $(\mathrm{A}, \mathrm{C}) \mathrm{Fe}^{\mathrm{III}}{ }_{4}\left[\left\{\mathrm{Fe}^{\mathrm{II}}(\mathrm{CN})_{6}\right\}_{3}\right]$ and $(\mathrm{B}, \mathrm{D}) \mathrm{Fe}_{3} \mathrm{II}_{3}\left[\left\{\mathrm{Co}^{\mathrm{III}}(\mathrm{CN})_{6}\right\}_{2}\right]$. Performance tests were conducted in an aqueous solution of $\mathrm{HClO}_{4}[(\mathrm{~A}, \mathrm{~B}): \mathrm{pH} 3 ;(\mathrm{C}, \mathrm{D}): \mathrm{pH}$ 1] that contained $\mathrm{H}_{2} \mathrm{O}_{2}(0.30 \mathrm{M})$ and $\mathrm{NaCl}(1.0 \mathrm{M})$. Currents and powers were normalized by a geometric surface area of electrode. ${ }^{74}$ 
The catalytic activity of polynuclear cyanide complexes for $\mathrm{H}_{2} \mathrm{O}_{2}$ reduction was effectively enhanced by modification of framework structure. ${ }^{75}$ The window size of homoleptic polynuclear cyanide complexes, in which the $\mathrm{C}-\mathrm{N}$ bond $(1.13 \AA)$ is shorter than the $\mathrm{O}-\mathrm{O}$ bond of $\mathrm{H}_{2} \mathrm{O}_{2}(1.46 \AA)$, can be expanded by the combination of a polynuclear cyanide complex forming a layered structure and a bridging extraligand larger than the cyanide ligand. ${ }^{75}$ The $2 \mathrm{D}$ layers of $\mathrm{Fe}\left[\mathrm{M}(\mathrm{CN})_{4}\right](\mathrm{M}=\mathrm{Pt}$ or $\mathrm{Pd})$ connected with pyrazine molecules have been reported to have porous structure with a large opening window. The $\mathrm{N} \cdots \mathrm{N}$ distance of pyrazine is $2.80 \AA$, which is considerably longer than the $\mathrm{C}-\mathrm{N}$ bond length of the cyanide ligand $(1.13 \AA)$. Also, pyrazine is known as a weakly bound ligand with a $\mathrm{p} K_{\mathrm{b}}$ value of 13 , so that the $\mathrm{Fe}^{2+}$ ions are expected to interact with $\mathrm{H}_{2} \mathrm{O}_{2}$ although the pyrazine molecules coordinate to $\mathrm{Fe}^{2+}$ ions. ${ }^{75}$ The performance of a one-compartment fuel cells using $\mathrm{H}_{2} \mathrm{O}_{2}$ was evaluated with carbon-cloth cathodes mounting $\mathrm{Fe}\left[\mathrm{M}(\mathrm{CN})_{4}\right](\mathrm{M}=\mathrm{Pt}$ or $\mathrm{Pd})$ using the drop-casting method and a nickel mesh anode in an aqueous solution $\left(\mathrm{HClO}_{4}, \mathrm{pH} 1\right.$ or 3$)$ that contained $0.30 \mathrm{M} \mathrm{H}_{2} \mathrm{O}_{2}$ at room temperature (Fig. 26a, b).$^{75}$ The open-circuit potential
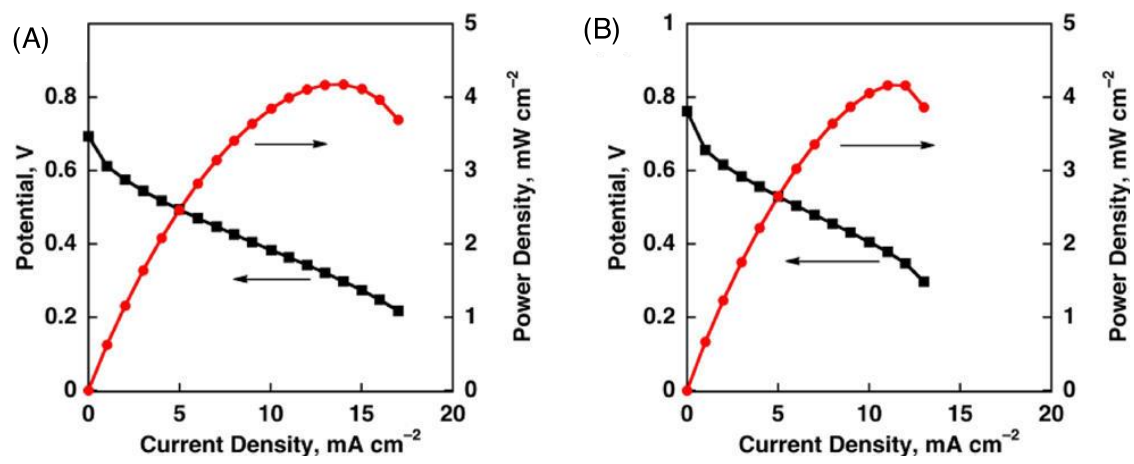

Fig. 26. $I-V$ (black) and $I-P$ (red) curves of a one-compartment $\mathrm{H}_{2} \mathrm{O}_{2}$ fuel cell with a nickel anode and a carbon-cloth electrode modified with a pyrazine-bridged cyanide complexes pyrazine-bridged $\mathrm{Fe}\left[\mathrm{M}^{\mathrm{C}}(\mathrm{CN})_{4}\right]$ complex $\left[\mathrm{M}^{\mathrm{C}}=(\mathrm{A}) \mathrm{Pt}^{2+}\right.$ and $\left.(\mathrm{B}) \mathrm{Pd}^{2+}\right]$. Performance tests were conducted in an aqueous solution of $\mathrm{HClO}_{4}(\mathrm{pH} 1)$ that contained $\mathrm{H}_{2} \mathrm{O}_{2}(0.30 \mathrm{M})$ and $\mathrm{NaCl}(1.0 \mathrm{M})$. Currents and powers were normalized by the geometric surface area of an electrode. ${ }^{75}$ 
of each $\mathrm{H}_{2} \mathrm{O}_{2}$ fuel cell operating at $\mathrm{pH} 1$ was between 0.70 and $0.80 \mathrm{~V}$. The power density of the $\mathrm{H}_{2} \mathrm{O}_{2}$ fuel cells with complexes containing $\mathrm{Pt}$ and $\mathrm{Pd}$ reached $4.2 \mathrm{~mW}$ $\mathrm{cm}^{-2}$, which is more than double compared to the highest value $\left(1.5 \mathrm{~mW} \mathrm{~cm}{ }^{-2}\right)$ reported for one- compartment $\mathrm{H}_{2} \mathrm{O}_{2}$ fuel cells using homoleptic polymeric cyanide complexes. These results clearly indicate that using pyrazine as the bridging ligand improves the performance of the one-compartment $\mathrm{H}_{2} \mathrm{O}_{2}$ fuel cells in terms of power density. ${ }^{75}$

\section{b. Porphyrin / Phthalocyanine Complexes}

Iron tetramethoxy phenyl porphyrin (FeTMPP/C) was utilized as a cathode to build direct borohydride fuel cells employing the $\mathrm{AB}_{5}$-alloy $\left(\mathrm{Mm} \mathrm{Ni}_{3.55} \mathrm{Al}_{0.3} \mathrm{Mn}_{0.4} \mathrm{Co}_{0.75}\right.$, $\mathrm{Mm}=$ Mischmetal) supported on carbon as an anode catalysts. The fuel cell operated with an aqueous solution containing $10 \mathrm{wt} \% \mathrm{NaBH}_{4}$ and $20 \mathrm{wt} \% \mathrm{NaOH}$ as an anolyte and that containing $0.5 \mathrm{M} \mathrm{H}_{2} \mathrm{O}_{2}$ and $0.5 \mathrm{M} \mathrm{H}_{2} \mathrm{SO}_{4}$ as a catholyte at temperatures between 30 and $70{ }^{\circ} \mathrm{C} .{ }^{76}$ Cyclic voltammograms of $\mathrm{H}_{2} \mathrm{O}_{2}$ in an acidic solution were measured with FeTMPP/C electrode showed that the onset potential for $\mathrm{H}_{2} \mathrm{O}_{2}$ reduction is $\sim 0.8 \mathrm{~V} .{ }^{76}$ Maximum power densities of the fuel cell operating at the temperatures at 30,50 and $70{ }^{\circ} \mathrm{C}$ reached 18,53 and $82 \mathrm{~mW} \mathrm{~cm}^{-2}$ at respective cell potentials of 0.5 , 0.53 and $0.5 \mathrm{~V}$, respectively (Fig. 27). ${ }^{76}$

Not only porphyrin but also phthalocyanine (Pc) was also used as cathode of a one-compartment $\mathrm{H}_{2} \mathrm{O}_{2}$ fuel cell using $\mathrm{Ni}$ as an anode. ${ }^{77}$ The performance of the fuel cell was examined in buffer solutions containing $300 \mathrm{mM} \mathrm{H}_{2} \mathrm{O}_{2}$ at $\mathrm{pH} \mathrm{3-5.77}$ The maximum power density remained lower than $1 \mu \mathrm{W} \mathrm{cm}{ }^{-2}$ at $\mathrm{pH} 4-5$, however, the maximum power density exceeded $10 \mu \mathrm{W} \mathrm{cm}{ }^{-2}$ at $\mathrm{pH} 3$ (Fig. 28). ${ }^{77}$ Such $\mathrm{pH}$ dependence was not observed for the fuel cells employing porphyrin compounds as cathode catalysts. ${ }^{77}$ The improvement of the catalytic activity at lower $\mathrm{pH}$ resulted from the molecular structure of the phthalocyanine ligand, which possesses nitrogens at mesopositions. ${ }^{77}$ Protonation to the nitrogens at lower $\mathrm{pH}$, which was evidenced by an acid titration of $\left[\mathrm{Fe}^{\mathrm{III}}(\mathrm{Pc}) \mathrm{Cl}\right]$ (Fig. 29), effectively increased the reducing activity for 
(A)

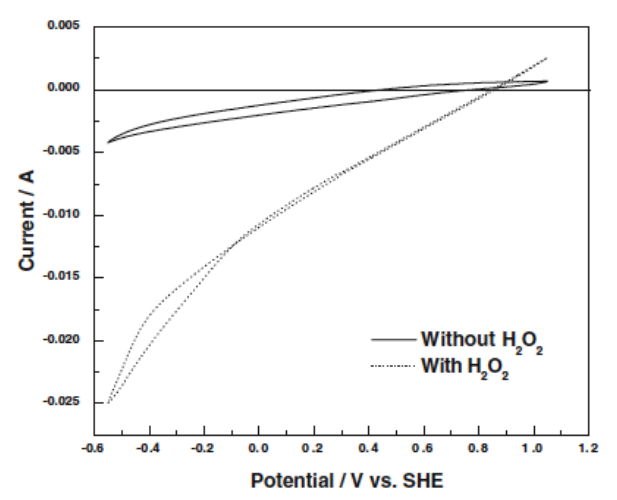

(B)

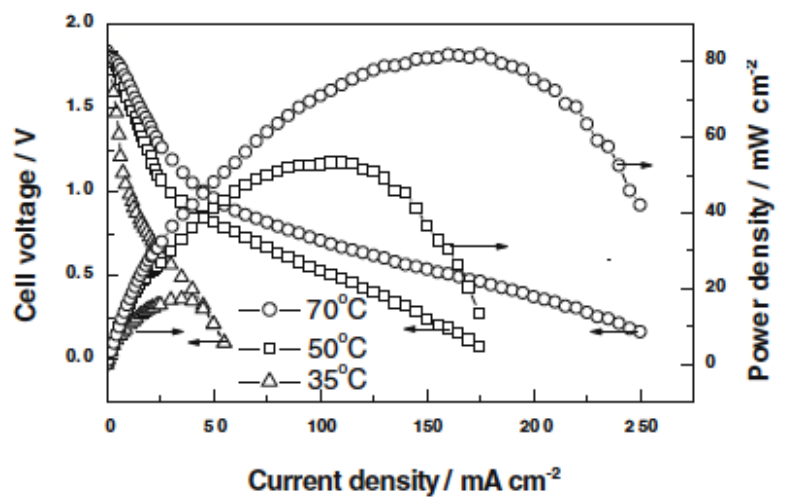

Fig. 27. (A) Cyclic voltammograms of $\mathrm{H}_{2} \mathrm{O}_{2}$ on the FeTMPP/C electrode in aqueous 0.5 $\mathrm{M}$ sulfuric acid with and without $0.5 \mathrm{M} \mathrm{H}_{2} \mathrm{O}_{2}$ and (B) Cell polarization curves for the $\mathrm{NaBH}_{4} / \mathrm{H}_{2} \mathrm{O}_{2}$ fuel cell with FeTMPP/C cathode operating at temperatures between 30 and $70{ }^{\circ} \mathrm{C}$ with alkaline aq. $\mathrm{NaBH}_{4}$ as an anolyte and an aqueous solution of $0.5 \mathrm{M}$ $\mathrm{H}_{2} \mathrm{O}_{2}$ and $0.5 \mathrm{M}$ sulfuric acid as a catholyte. ${ }^{76}$

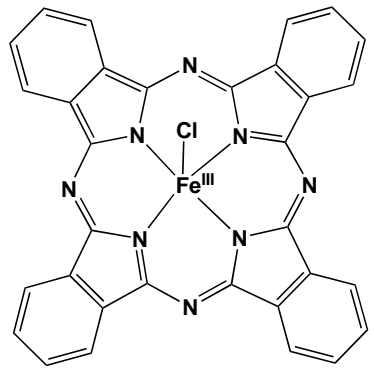

$\left[\mathrm{Fe}^{\mathrm{III}}(\mathrm{Pc}) \mathrm{Cl}\right]$
(A)

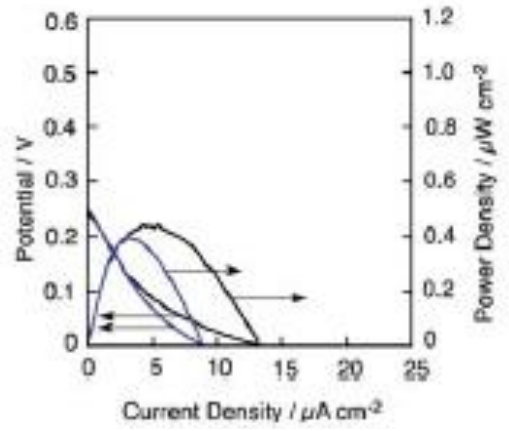

(B)

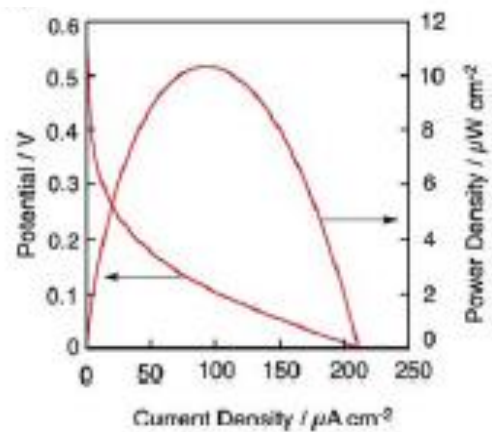

Fig. 28. $I-V$ and $I-P$ curves of a one-compartment $\mathrm{H}_{2} \mathrm{O}_{2}$ fuel cell with $\mathrm{Ni}$ anode and $\left[\mathrm{Fe}^{\mathrm{III}}(\mathrm{Pc}) \mathrm{Cl}\right]$ cathode. Performance tests were conducted in an acetate buffer containing $300 \mathrm{mM} \mathrm{H}_{2} \mathrm{O}_{2}$. The $\mathrm{pH}$ of the solutions was fixed to 5 (a, blue), 4 (a, black) or 3 (b, red). Currents and powers were normalized by a geometric surface area of electrode. ${ }^{77}$ 
(A)

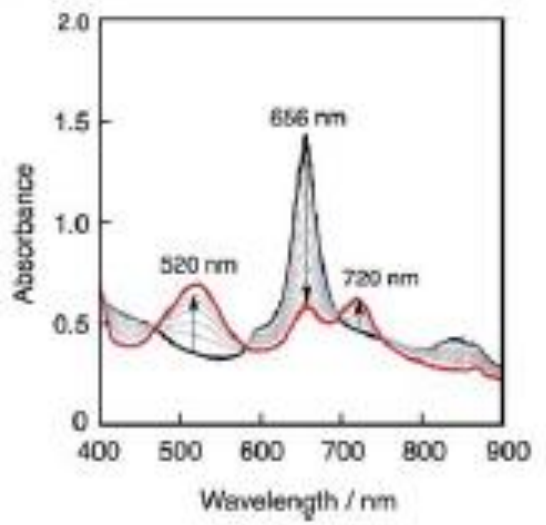

(B)

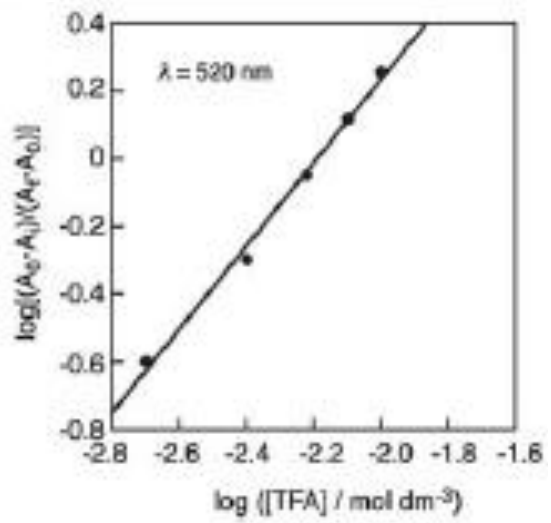

Fig. 29. (A) UV-vis absorption change of a benzonitrile solution of $\left[\mathrm{Fe}^{\mathrm{III}}(\mathrm{Pc}) \mathrm{Cl}\right](0.04$ $\mathrm{mM}$ ) by adding trifluoroacetic acid $(2-16 \mathrm{mM})$. (B) The Hill plot obtained by absorption change at $520 \mathrm{~nm} .^{77}$

$\mathrm{H}_{2} \mathrm{O}_{2}$ because the protonation induces the positive shift of the redox potential of $\left[\mathrm{Fe}^{\mathrm{II} / \mathrm{III}}(\mathrm{Pc}) \mathrm{Cl}\right]$ to stabilize the $\mathrm{Fe}{ }^{\mathrm{II}}$ state..$^{77}$

\section{Others}

a. Carbon A $\mathrm{Mg}-\mathrm{H}_{2} \mathrm{O}_{2}$ fuel cell was constructed with noble metal free carbon based cathode. ${ }^{78}$ A schematic drawing of the $\mathrm{Mg} / \mathrm{H}_{2} \mathrm{O}_{2}$ fuel cell is indicated in Fig. 30. Two

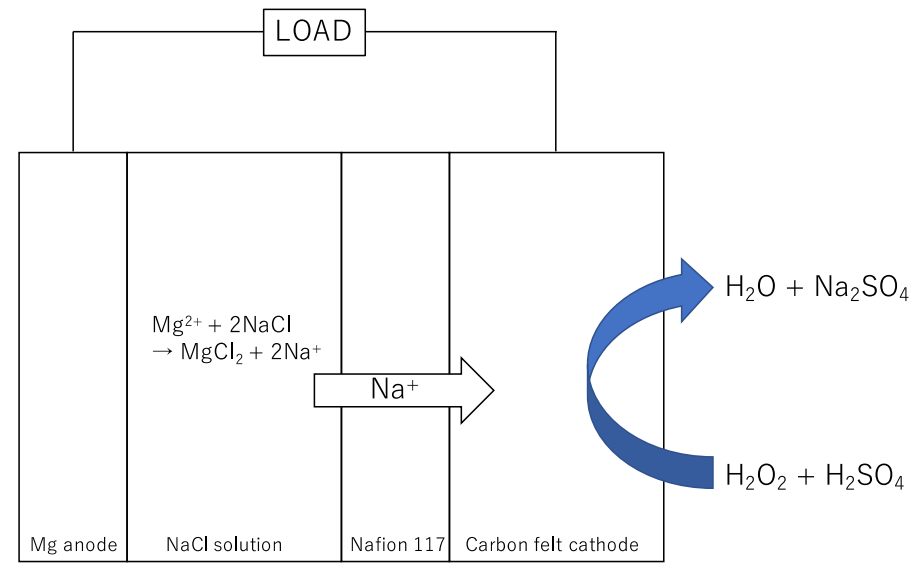

Fig. 30. Schematic drawing of a $\mathrm{Mg} / \mathrm{H}_{2} \mathrm{O}_{2}$ fuel cell using carbon felt as the cathode. ${ }^{78}$

chambers were separated by Nafion 117, which acts as $\mathrm{Na}^{+}$ion conductor. ${ }^{78}$ The chamber for $\mathrm{Mg}$ alloy (AZ61) anode contains $0.6 \mathrm{M} \mathrm{NaCl}$ solution and that for carbon 
cloth or carbon felt cathode was supplied catholyte containing $2.0 \mathrm{M} \mathrm{H}_{2} \mathrm{O}_{2}$ and $2.0 \mathrm{M}$ $\mathrm{H}_{2} \mathrm{SO}_{4}$ with flow rate of $50 \mathrm{~mL} \mathrm{~min}{ }^{-1}{ }^{78}$ Although both carbon cloth and carbon felt acted as cathodes, carbon felt exhibited smaller cathodic polarization. Power density of the cell reached $91 \mathrm{~mW} \mathrm{~cm}^{-2}$ and maintained for $26 \mathrm{~h}$ under optimized conditions. ${ }^{78}$

b. $\mathbf{P b S O}_{4} \mathrm{PbSO}_{4}$ was employed as an active component of cathodes in a $\mathrm{NaBH}_{4} / \mathrm{H}_{2} \mathrm{O}_{2}$ and $\mathrm{H}_{2} \mathrm{O}_{2} / \mathrm{H}_{2} \mathrm{O}_{2}$ fuel cells. Catalytic activity of $\mathrm{PbSO}_{4}$ supported on carbon (Vulcan XC-72R) for $\mathrm{H}_{2} \mathrm{O}_{2}$ reduction was examined in $0.5 \mathrm{M}$ sulfuric acid. ${ }^{76}$ The reduction of $\mathrm{H}_{2} \mathrm{O}_{2}$ started at $0.75 \mathrm{~V}$ as indicated in Fig. $31 \mathrm{~A} .{ }^{76}$ The $\mathrm{NaBH}_{4} / \mathrm{H}_{2} \mathrm{O}_{2}$ fuel cell using
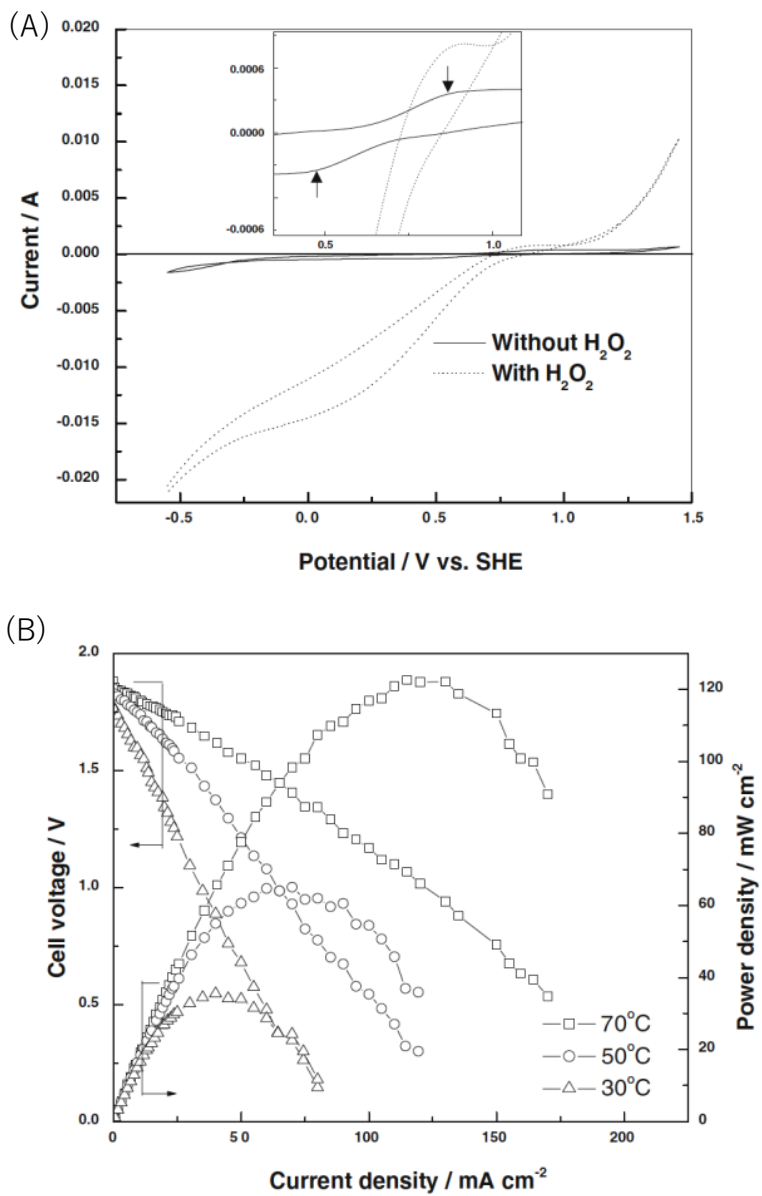

Fig. 31. (A) Cyclic voltammograms of $\mathrm{H}_{2} \mathrm{O}_{2}$ on a $\mathrm{PbSO}_{4} / \mathrm{C}$ electrode in aqueous sulfuric acid with and without $0.5 \mathrm{M} \mathrm{H}_{2} \mathrm{O}_{2}$. (B) Cell polarization data for the fuel cell operating at temperatures between 30 and $70{ }^{\circ} \mathrm{C}$ with feeding alkaline aq. $\mathrm{NaBH}_{4}$ and $0.5 \mathrm{M} \mathrm{H}_{2} \mathrm{O}_{2}$ in $0.5 \mathrm{M}$ sulfuric acid solution to the anode and cathode, respectively. ${ }^{76}$ 
$\mathrm{PbSO}_{4} / \mathrm{C}$ and $\mathrm{AB}_{5}$ alloy composed of $\mathrm{Ni}, \mathrm{Al}, \mathrm{Mn}$ and $\mathrm{Co}$ showed the maximum power density of $120 \mathrm{~mW} \mathrm{~cm}^{-2}$ operating at $70{ }^{\circ} \mathrm{C}$ (Fig. 31B). ${ }^{76}$

$\mathrm{PbSO}_{4}$ supported on carbon paper $\left(\mathrm{PbSO}_{4} / \mathrm{CP}\right)$ prepared by electroless deposition was employed as the cathode of a $\mathrm{H}_{2} \mathrm{O}_{2} / \mathrm{H}_{2} \mathrm{O}_{2}$ fuel cell together with $\mathrm{Ni}$ anode. ${ }^{3}$ The fuel cell used a basic $\mathrm{H}_{2} \mathrm{O}_{2}$ solution $\left(3 \mathrm{M} \mathrm{KOH}+1 \mathrm{M} \mathrm{H}_{2} \mathrm{O}_{2}\right)$ as an anolyte and an acidic $\mathrm{H}_{2} \mathrm{O}_{2}$ solution (1.5 $\mathrm{M} \mathrm{H}_{2} \mathrm{SO}_{4}+1 \mathrm{M} \mathrm{H}_{2} \mathrm{O}_{2}$ ) as a catholyte. The power density obtained from the fuel cell $\left(10 \mathrm{~mW} \mathrm{~cm} \mathrm{~cm}^{-2}\right)$ was more than double that of a fuel cell using $\mathrm{Pt} / \mathrm{CP}$ cathode instead of $\mathrm{PbSO}_{4} / \mathrm{CP}\left(4 \mathrm{~mW} \mathrm{~cm}^{-2}\right)$, suggesting that $\mathrm{PbSO}_{4}$ is a better catalyst than $\mathrm{Pt}$ for electroreduction of $\mathrm{H}_{2} \mathrm{O}_{2}$ (Fig. 32). ${ }^{3}$

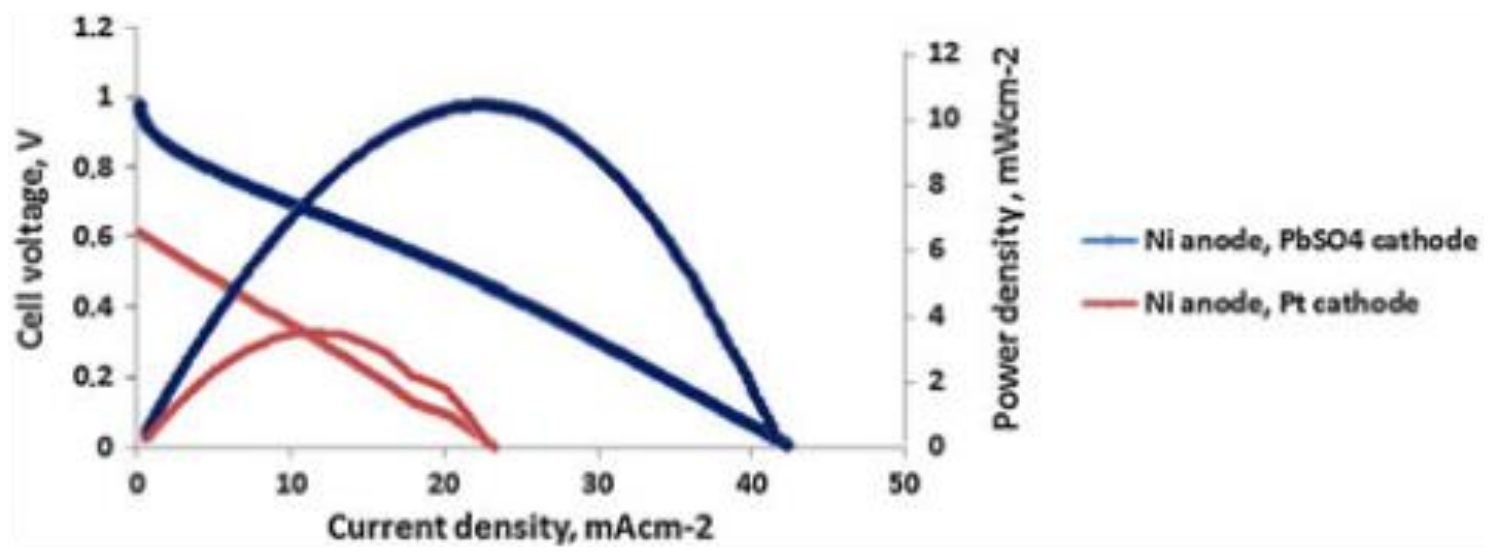

Fig. 32. Polarization curves and power curves of a passive $\mathrm{H}_{2} \mathrm{O}_{2} / \mathrm{H}_{2} \mathrm{O}_{2}$ fuel cell constructed with $\mathrm{Ni} / \mathrm{C}$ anode and $\mathrm{PbSO}_{4} / \mathrm{C}$ (solid circle) and $\mathrm{Pt} / \mathrm{C}$ (frame circle) cathodes. Operating conditions: $3 \mathrm{M} \mathrm{KOH}+1 \mathrm{M} \mathrm{H}_{2} \mathrm{O}_{2}$ as anolyte and $1.5 \mathrm{M} \mathrm{H}_{2} \mathrm{SO}_{4}+1$ $\mathrm{M} \mathrm{H}_{2} \mathrm{O}_{2}$ as catholyte at $25^{\circ} \mathrm{C} .^{3}$

\section{Conclusion}

Various types of fuel cells were constructed by employing metal, metal oxide and metal complexes as cathodes, where electrochemical $\mathrm{H}_{2} \mathrm{O}_{2}$ reduction proceeds. Molecular oxygen $\left(\mathrm{O}_{2}\right)$ often used as an oxidant for contracting fuel cells is abundant and free of charge, however, oxygen reduction involves four electrons and four protons to form two water molecules that is hard reaction from the kinetic point of view. $\mathrm{H}_{2} \mathrm{O}_{2}$ produced by two electron reduction of $\mathrm{O}_{2}$ is more easily reduced to water by 
two-electron reduction $\left(\mathrm{H}_{2} \mathrm{O}_{2}+2 \mathrm{H}^{+}+2 \mathrm{e}^{-}=2 \mathrm{H}_{2} \mathrm{O} ; E^{\mathrm{o}}=1.78 \mathrm{~V}\right.$ vs NHE$)$ than $\mathrm{O}_{2}\left(\mathrm{O}_{2}+\right.$ $4 \mathrm{H}^{+}+4 \mathrm{e}^{-}=2 \mathrm{H}_{2} \mathrm{O} ; E^{\mathrm{o}}=1.23 \mathrm{~V}$ vs NHE) from both kinetic and thermodynamic points of views. The high reduction potential is beneficial to construct fuel cells with high power density and high voltage. In fact, some fuel cells using metal anode or borohydride fuel accomplished high power density and voltages. However, a couple of problems should be overcome to extend this success to other fuel cells. For examples, many cathodes show catalytic activity not only for $\mathrm{H}_{2} \mathrm{O}_{2}$ reduction but also for $\mathrm{H}_{2} \mathrm{O}_{2}$ decomposition by disproportionation. Additionally, $\mathrm{H}_{2} \mathrm{O}_{2}$ is a strong oxidizer that can corrode organic parts of fuel cells, probably because of formation of highly reactive $\mathrm{OH}^{*}$ by the one-electron reduction of $\mathrm{H}_{2} \mathrm{O}_{2}$. Negative potential of one-electron reduction of $\mathrm{H}_{2} \mathrm{O}_{2}\left(\mathrm{H}_{2} \mathrm{O}_{2}+\mathrm{H}^{+}+\mathrm{e}^{-}=\mathrm{OH}^{\bullet}+\mathrm{H}_{2} \mathrm{O} ; E^{\mathrm{o}}=1.14 \mathrm{~V}\right.$ vs NHE$)$ compared with two electron reduction indicates one-electron reduction is thermodynamically unfavorable, however, one-electron reduction may occur faster than two-electron reduction. Not only active but also selective cathodes for two-electron reduction of $\mathrm{H}_{2} \mathrm{O}_{2}$ should be developed to achieve high power fuel cells using $\mathrm{H}_{2} \mathrm{O}_{2}$ as an oxidant. Suitable catalysts for two-electron reduction of $\mathrm{H}_{2} \mathrm{O}_{2}$ would be found in electrodes used in $\mathrm{H}_{2} \mathrm{O}_{2}$ detection sensors but not used in fuel cells, such as shape-controlled metal nanoparticles, ${ }^{79,80}$ graphene based materials, ${ }^{81-83}$ polyoxometalate, ${ }^{84-88}$ and metal complexes. ${ }^{89,90}$

\section{Acknowledgements}

The authors gratefully acknowledge the contributions of their collaborators and coworkers cited in references, and support by funds from the Ministry of Education, Culture, Sports, Science and Technology, Japan. ENEOS hydrogen trust funding.

\section{References}

(1) Bard, A. J.; Parsons, R.; Jordan, J. ed. Standard Potentials in Aqueous Solution; Marcel Dekker, 1985.

(2) Disselkamp, R. S. Energy Fuels 2008, 22, 2771. 
(3) Sanli, A. E. Int. J. Energy Res. 2013, 37, 1488.

(4) Fukuzumi, S.; Yamada, Y.; Karlin, K. D. Electrochim. Acta 2012, 82, 493.

(5) Fukuzumi, S.; Yamada, Y. ChemElectroChem 2016, 3, 1978.

(6) Isaka, Y.; Oyama, K.; Yamada, Y.; Suenobu, T.; Fukuzumi, S. Catal. Sci. Technol. 2016, 6, 681 .

(7) Shiraishi, Y.; Kanazawa, S.; Kofuji, Y.; Sakamoto, H.; Ichikawa, S.; Tanaka, S.; Hirai, T. Angew. Chem. Int. Ed. 2014, 53, 13454-13459.

(8) Mase, K.; Yoneda, M.; Yamada, Y.; Fukuzumi, S. Nat. Commun. 2016, 7.

(9) Hasegawa, S.; Shimotani, K.; Kishi, K.; Watanabe, H. Electrochem. Solid-State Lett. 2005, 8, A119.

(10) Kjeang, E.; Brolo, A. G.; Harrington, D. A.; Djilali, N.; Sinton, D. J. Electrochem. Soc. 2007, 154, B1220.

(11) Huo, W. W.; Zhou, Y.; Zhang, H. F.; Zou, Z. Q.; Yang, H. Int. J. Electrochem. Sci. 2013, 8, 4827.

(12) Sangarunlert, W.; Sukchai, S.; Pongtornkulpanich, A.; Nathakaranakule, A.; Luschtinetz, T. J. Fuel Cell Sci. Technol. 2011, 8.

(13) Santos, D. M. F.; Sequeira, C. A. C. J. Electrochem. Soc. 2010, 157, B13.

(14) Santos, D. M. F.; Balciunaite, A.; Tamasauskaite-Tamasiunaite, L.; Zabielaite, A.; Jagminiene, A.; Stankeviciene, I.; Naujokaitis, A.; Norkus, E. J. Electrochem. Soc. 2016, 163, F1553.

(15) Wang, Y. G.; He, P.; Zhou, H. S. Energy Environ. Sci. 2010, 3, 1515.

(16) Sanli, A. E.; Aksu, M. L.; Uysal, B. Z. Int. J. Hydrogen Energy 2011, 36, 8542.

(17) Kim, J.; Jang, B.; Lee, T.; Kwon, S. Int. J. Tubo Jet-Engines 2015, 32, 291.

(18) Luo, N.; Miley, G. H.; Gimlin, R.; Burton, R.; Rusek, J.; Holcomb, F. J. Propul. Power 2008, 24, 583.

(19) Oh, T. H.; Jang, B.; Kwon, S. Int. J. Hydrogen Energy 2014, 39, 6977.

(20) Brodrecht, D. J.; Rusek, J. J. Appl. Energy 2003, 74, 113.

(21) Serov, A.; Kwak, C. Appl. Catal., B 2010, 98, 1.

(22) Yan, X. L.; Meng, F. H.; Xie, Y.; Liu, J. G.; Ding, Y. Sci. Rep. 2012, 2.

(23) Lao, S. J.; Qin, H. Y.; Ye, L. Q.; Liu, B. H.; Li, Z. P. J. Power Sources 2010, 195, 4135.

(24) Guo, F.; Cheng, K.; Ye, K.; Wang, G. L.; Cao, D. X. Electrochim. Acta 2016, 199, 290. 
(25) Yang, F.; Cheng, K.; Liu, X. L.; Chang, S.; Yin, J. L.; Du, C. Y.; Du, L.; Wang, G. L.; Cao, D. X. J. Power Sources 2012, 217, 569.

(26) Yang, F.; Cheng, K.; Mo, Y. H.; Yu, L. Q.; Yin, J. L.; Wang, G. L.; Cao, D. X. J. Power Sources 2012, 217, 562.

(27) Yang, F.; Cheng, K.; Xue, X.; Yin, J. L.; Wang, G. L.; Cao, D. X. Electrochim. Acta 2013, 107, 194.

(28) Yang, F.; Cheng, K.; Xiao, X.; Yin, J. L.; Wang, G. L.; Cao, D. X. J. Power Sources 2014, 245, 89.

(29) Ye, K.; Guo, F.; Gao, Y. Y.; Zhang, D. M.; Cheng, K.; Zhang, W. P.; Wang, G. L.; Cao, D. X. J. Power Sources 2015, 300, 147.

(30) Dow, E. G.; Bessette, R. R.; Seeback, G. L.; Marsh-Orndorff, C.; Meunier, H.; VanZee, J.; Medeiros, M. G. J. Power Sources 1997, 65, 207.

(31) Bessette, R. R.; Cichon, J. M.; Dischert, D. W.; Dow, E. G. J. Power Sources 1999, 80, 248.

(32) Bessette, R. R.; Medeiros, M. G.; Patrissi, C. J.; Deschenes, C. M.; LaFratta, C. N. J. Power Sources 2001, 96, 240.

(33) Medeiros, M. G.; Bessette, R. R.; Deschenes, C. M.; Patrissi, C. J.; Carreiro, L. G.; Tucker, S. P.; Atwater, D. W. J. Power Sources 2004, 136, 226.

(34) Patrissi, C. J.; Bessette, R. R.; Kim, Y. K.; Schumacher, C. R. J. Electrochem. Soc. 2008, 155, B558.

(35) Shu, C. Z.; Wang, E. D.; Jiang, L. H.; Tang, Q. W.; Sun, G. Q. J. Power Sources 2012, 208, 159.

(36) Yamazaki, S. I.; Siroma, Z.; Senoh, H.; Loroi, T.; Fujiwara, N.; Yasuda, K. J. Power Sources 2008, 178, 20.

(37) Yamada, Y.; Fukunishi, Y.; Yamazaki, S.; Fukuzumi, S. Chem. Commun. 2010, 46, 7334.

(38) Yang, W.; Yang, S.; Sun, W.; Sun, G.; Xin, Q. J. Power Sources 2006, 160, 1420.

(39) Yang, W. Q.; Yang, S. H.; Sun, W.; Sun, G. Q.; Xin, Q. Electrochim. Acta 2006, 52,9 .

(40) Liu, K.; Wang, C. A.; Ma, J. T. RSC Adv. 2014, 4, 18894.

(41) Lei, T.; Tian, Y. M.; Wang, G. L.; Yin, J. L.; Gao, Y. Y.; Wen, Q.; Cao, D. X. Fuel Cells 2011, 11, 431.

(42) Zhuang, S. X.; Liu, S. Q.; Zhang, J. B.; Tu, F. Y.; Huang, H. X.; Huang, K. L.; Li, 
Y. H. Acta Phys.-Chim. Sin. 2012, 28, 355.

(43) Santos, D. M. F.; Gomes, T. F. B.; Sljukic, B.; Sousa, N.; Sequeira, C. A. C.; Figueiredo, F. M. L. Electrochim. Acta 2015, 178, 163.

(44) Wu, H. J.; Wang, C.; Liu, Z. X.; Mao, Z. Q. Int. J. Hydrogen Energy 2010, 35, 2648.

(45) Karyakin, A. A.; Karyakina, E. E.; Gorton, L. J. Electroanal. Chem. 1998, 456, 97.

(46) Karyakin, A. A.; Karyakina, E. E.; Gorton, L. Electrochem. Commun. 1999, 1, 78.

(47) Eftekhari, A. Talanta 2001, 55, 395.

(48) Karyakin, A. A. Electroanalysis 2001, 13, 813.

(49) Zhao, G.; Feng, J. J.; Zhang, Q. L.; Li, S. P.; Chen, H. Y. Chem. Mater. 2005, 17, 3154.

(50) Kumar, S. M. S.; Pillai, K. C. Electrochem. Commun. 2006, 8, 621.

(51) Qiu, J.-D.; Peng, H.-Z.; Liang, R.-P.; Li, J.; Xia, X.-H. Langmuir 2007, 23, 2133.

(52) Yu, H.; Sheng, Q. L.; Zheng, J. B. Electrochim. Acta 2007, 52, 4403.

(53) Baioni, A. P.; Vidotti, M.; Fiorito, P. A.; de Toressi, S. I. C. J. Electroanal. Chem. 2008, 622, 219.

(54) Ding, H.; Zhao, L.; Li, Y.; He, X. Asian J. Chem. 2008, 20, 2327.

(55) Jia, F.; Yu, C.; Gong, J.; Zhang, L. J. Solid State Electrochem. 2008, 12, 1567.

(56) Ojani, R.; Raoof, J.-B.; Fathi, S. J. Solid State Electrochem. 2009, 13, 837.

(57) Iveković, D.; Gajović, A.; Čeh, M.; Pihlar, B. Electroanalysis 2010, 22, 2202.

(58) Jin, E.; Lu, X.; Cui, L.; Chao, D.; Wang, C. Electrochim. Acta 2010, 55, 7230.

(59) Lisowska-Oleksiak, A.; Wilamowska, M.; Jasulaitiene, V. Electrochim. Acta 2011, 56, 3626.

(60) Tsai, T.-H.; Chen, T.-W.; Chen, S.-M. Int. J. Electrochem. Sci. 2011, 6, 4628.

(61) Yang, H.; Yuan, R.; Chai, Y.; Su, H.; Zhuo, Y.; Jiang, W.; Song, Z. Electrochim. Acta 2011, 56, 1973.

(62) Chen, L.; Wang, X.; Zhang, X.; Zhang, H. J. Mater. Chem. 2012, 22, 22090.

(63) Chen, S.-M.; Wang, C.-H.; Lin, K.-C. Int. J. Electrochem. Sci. 2012, 7, 405.

(64) Iveković, D.; Trbić, H. V.; Peter, R.; Petravić, M.; Čeh, M.; Pihlar, B. Electrochim. Acta 2012, 78, 452.

(65) Jin, R.; Li, L.; Lian, Y.; Xu, X.; Zhao, F. Anal. Methods 2012, 4, 2704. 
(66) Mao, H.; Song, J.; Zhang, Q.; Liu, D.; Gong, N.; Li, Y.; Wu, Q.; Verpoort, F.; Song, X.-M. Nanotechnology 2013, 24.

(67) Doroftei, F.; Pinteala, T.; Arvinte, A. Microchimica Acta 2014, 181, 111.

(68) Mendes Castro Junior, J. G.; Mota Ferreira, G. M.; de Oliveira, F. G.; Damos, F. S.; Silva Luz, R. d. C. J. Electroanal. Chem. 2014, 732, 93.

(69) Gong, K. J. Colloid Interface Sci. 2015, 449, 80.

(70) Jomma, E. Y.; Bao, N.; Ding, S.-N. Curr. Anal. Chem. 2016, 12, 512.

(71) Karpova, E.; Karyakina, E. E.; Karyakin, A. A. RSC Adv. 2016, 6, 103328.

(72) Santos, D. M. F.; Saturnino, P. G.; Lobo, R. F. M.; Sequeira, C. A. C. J. Power Sources 2012, 208, 131.

(73) Shaegh, S. A. M.; Nguyen, N. T.; Ehteshami, S. M. M.; Chan, S. H. Energy Environ. Sci. 2012, 5, 8225.

(74) Yamada, Y.; Yoneda, M.; Fukuzumi, S. Chem.-Eur. J. 2013, 19, 11733.

(75) Yamada, Y.; Yoneda, M.; Fukuzumi, S. Inorg. Chem. 2014, 53, 1272.

(76) Raman, R. K.; Shukla, A. K. J. Appl. Electrochem. 2005, 35, 1157.

(77) Yamada, Y.; Yoshida, S.; Honda, T.; Fukuzumi, S. Energy Environ. Sci. 2011, 4, 2822.

(78) Mahesh, K.; Balaji, R.; Dhathathreyan, K. S. Ionics 2015, 21, 2603.

(79) Hernandez, J.; Solla-Gullon, J.; Herrero, E.; Feliu, J. M.; Aldaz, A. J. Nanosci. Nanotechnol. 2009, 9, 2256.

(80) Yang, X.; Ouyang, Y.; Wu, F.; Hu, Y.; Ji, Y.; Wu, Z. Sens. Actuators, B 2017, 238, 40.

(81) Tian, Y. M.; Huang, J. C.; Gao, Y.; Cao, D. X.; Wang, G. L. J. Solid State Electrochem. 2012, 16, 1901.

(82) Amirfakhri, S. J.; Pascone, P. A.; Meunier, J. L.; Berk, D. J. Catal. 2015, 323, 55.

(83) Zhang, R. Z.; Chen, W. Biosens. Bioelectron. 2017, 89, 249.

(84) Ernst, A. Z.; Zoladek, S.; Wiaderek, K.; Cox, J. A.; Kolary-Zurowska, A.; Miecznikowski, K.; Kulesza, P. J. Electrochim. Acta 2008, 53, 3924.

(85) Hamidi, H.; Shams, E.; Yadollahi, B.; Esfahani, F. K. Electrochim. Acta 2009, 54, 3495.

(86) Wang, C.; Hua, Y.; Tong, Y. Electrochim. Acta 2010, 55, 6755.

(87) Liu, J. Y.; Cheng, L.; Dong, S. J. Electroanalysis 2002, 14, 569. 
(88) Martel, D.; Kuhn, A. Electrochim. Acta 2000, 45, 1829.

(89) Khoshro, H.; Zare, H. R.; Vafazadeh, R. Chin. J. Catal. 2014, 35, 247.

(90) Bagheri, H.; Ranjbari, E.; Amiri-Aref, M.; Hajian, A.; Ardakani, Y. H.; Amidi, S. Biosens. Bioelectron. 2016, 85, 814. 